\title{
Importance of ecological interactions during wastewater treatment using High Rate Algal Ponds under different temperate climates
}

\author{
Galès Amandine ${ }^{1,2}$, Bonnafous Anaïs ${ }^{2}$, Carré Claire ${ }^{5}$, Jauzein Vincent ${ }^{3}$, Lanouguère Elodie ${ }^{4}$, \\ Le Floc'h Emilie ${ }^{6}$, Pinoit Joanna ${ }^{3}$, Poullain Clothilde ${ }^{3}$, Roques Cécile ${ }^{4}$, Sialve Bruno ${ }^{7}$, \\ Simier Monique ${ }^{5}$, Steyer Jean-Philippe ${ }^{7}$, Fouilland Eric ${ }^{4,}$
}

${ }^{1}$ MARBEC, Univ Montpellier, IRD, IFREMER, CNRS, Sète \& Montpellier, France

${ }^{2}$ LBE, Univ Montpellier, INRA, 102 avenue des Etangs, 11100 Narbonne, France

${ }^{3}$ SAUR, Direction technique, 2 rue de la Bresle, 78310 Maurepas, France

* Corresponding author : Eric Fouilland, email address : eric.fouilland@cnrs.fr

\begin{abstract}
:
Several studies focused on wastewater treatment in High Rate Algal Ponds (HRAP) suggest that highly variable climatic conditions cause large variations of microalgal biomass productivity. In the present study, we show that similar carbon, nitrogen and phosphorus removal efficiencies were reached in different HRAPs treating urban wastewaters located in two different temperate (Mediterranean and oceanic) climates. Furthermore, similar ecological successions were observed in these HRAPs. During the start-up phase, the consumption of organic matter by detritivores, already present in the wastewater, appears to be necessary for the microalgae to grow within two weeks in spring. The growth of the rapidgrowing species, Chlorella sp., followed by the grazing-resilient species, Scenedesmus sp., combined with nitrifying and denitrifying bacterial activity, removed most the ammonia. The resulting exhaustion of ammonia would limit the complete removal of dissolved COD by bacteria and phosphate by microalgae in the HRAPs. This study shows that similar biological and environmental constraints were applied on the HRAPs, making the process efficiency highly reproducible under different temperate latitudes.
\end{abstract}




\section{Graphical abstract}

\section{SPRING AUTUMN}

\begin{tabular}{|l|l|}
\hline detrivores & bacteria \\
\hline microalgae & Dissolved COD removal \\
\hline
\end{tabular}

Phosphate removal

microalgae bacteria

Ammonia removal

\section{Highlights}

Similar ecological successions were observed under different temperate climates. Detritivores help wastewater clarification leading to the growth of algae. Nitrifying/denitrifying bacteria participated substantially in ammonia removal. Ammonia exhaustion limited algal phosphate and bacterial COD removal.

Keywords : Microalgae, Predators, Bacteria, Urban effluents, Ammonia and phosphate removal 


\section{Introduction}

The use of intensive microalgae cultivation systems such as High Rate Algal Ponds (HRAPs) has been found to be more efficient than conventional oxidation ponds in the treatment of organic and inorganic wastewater $[1,2]$. However, several studies using pilot plants have pointed out that the highly variable environmental conditions in HRAPs can cause large variations in microalgal biomass productivity under real-life operating conditions $[3,4,5,6]$. The presence of diverse grazer communities, the variable characteristics of the wastewater influent, and rapid changes in climatic conditions are all invoked to explain the changes in microalgae diversity and the resultant changes in their performance for nutrient removal $[7,8$, 9, 10]. However, little is known about the effects of the interactions between microorganisms already present in the wastewater and those that are growing in the HRAPs on carbon, nitrogen and phosphorus removal under real-life operating conditions. The association of microalgae and bacteria is usually proposed as a source of $\mathrm{O}_{2}$ and a $\mathrm{CO}_{2}$ supplementation, respectively, although they may compete for nutrients [10]. A recent study pointed out the importance of the presence, in the wastewater, of microalgae that may strongly influence both the diversity of the microalgal community growing in the HRAP and its productivity [7]. Cho et al. [9] also suggest that the high diversity within the microalgae community developing naturally in engineered system would help to sustain the whole community from different climatic conditions and predatory pressures. The objective of the present study is in perfect line with these findings. Indeed, the study was designed to assess if similar carbon, nitrogen and phosphorus removal efficiencies can be achieved between different geographical sites, the underlying reason being that indigenous bacterial and microalgal communities growing from wastewaters are the most adapted to local abiotic and biotic pressures. Under such natural 
conditions, we hypothesize that the optimal removal efficiencies will depend more on trophic interactions than on changes in climatic conditions

The present study investigated the dynamics of the bacterial, microalgal, protozoan and metazoan communities of two HRAPs continuously fed with wastewater, one located in the North of France under a typical oceanic climate and the other in the South of France under a typical Mediterranean climate. The biological succession observed is discussed together with the carbon, nitrogen and phosphorus removal performance of the HRAP and the biomass production during the first five months of operation.

\section{Materiel and Methods}

\subsection{HRAP operation and sample collection}

Two similar high rate algal pond (HRAPs) systems were connected to two different urban wastewater treatment plants, one in the North of France (Lat. $49^{\circ} 8^{\prime} 2^{\prime \prime} \mathrm{N}$, Long. $0^{\circ} 10^{\prime} 13^{\prime \prime} \mathrm{W}$ )

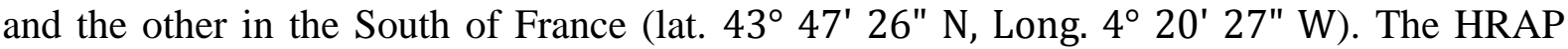
comprised a single-loop transparent polycarbonate raceway with an operating depth determined setting the outflow weir at a height of $400 \mathrm{~mm}$ giving a total treatment volume of $1.9 \mathrm{~m}^{3}$. The HRAPs were initially filled with pre-treated wastewater (after screening and removing grit, sand and grease) without adding any microalgal inoculum. A pump, with a flow rate of 1 to $5 \mathrm{~m}^{3} \cdot \mathrm{h}^{-1}$ and a $2.2 \mathrm{~mm}$ filter, recirculated the water through the HRAP. The HRAPs were run in continuous mode. The HRAPs were continuously topped up with wastewater at $315 \mathrm{~L}$ per day (equivalent to 2.1 persons equivalent in France) and the same volume of HRAP water was simultaneously discharged through the outflow weir, in order to 
keep the HRAP volume constant. A hydraulic retention time of 6 days was thus achieved. A buffer tank was installed before the HRAP at the northern site one month after the beginning of experiment. This tank was used to smooth potential abrupt fluctuations of the suspended solids in the wastewater at the northern site but it was not necessary for the southern site.

The HRAP at the northern site was in operation from the $28^{\text {th }}$ April 2015 to the $15^{\text {th }}$ September 2015. The HRAP at the southern site was in operation from the $20^{\text {th }}$ January 2016 to the $29^{\text {th }}$ September 2016 (first experimental run) and from the $12^{\text {th }}$ April 2017 to the $19^{\text {th }}$ May 2017 (second experimental run) after completely draining and cleaning the HRAP.

Environmental variables were measured using a radiometer and an air temperature sensor (Electrona, Parlite radiometer) for the northern site and a weather station (Vantage Pro2 Plus, Davis Instruments) for the southern site, located near the HRAPs recording rainfall, incident radiation and air temperature every $30 \mathrm{~min}$. The water temperature in the HRAPs was measured every 30 min using the temperature sensor in a $\mathrm{pH}$ immersion probe (pHD, Hach Lange). During the second experimental run in the southern site, the light attenuation was measured daily within the HRAP. Samples for chemical analyses (total and dissolved chemical oxygen demand, total and dissolved nitrogen, ammonia, nitrite, nitrate, total and dissolved phosphorus, phosphate, $\mathrm{pH}$, total alkalinity, total suspended solids) were taken from the HRAP and from the wastewater daily, for the whole experimental run at the northern site and daily for the first 3 months and then weekly for both experimental runs at the southern site. The carbon, nitrogen, phosphorus and chlorophyll $a$ contents in the biomass in the HRAPs were measured daily during the period when the microalgal biomass was growing and then every week. Samples for bacterial diversity analysis were taken weekly from the HRAPs and samples for microalgal, protozoan and metazoan analysis were taken monthly from the HRAPs (first run only for the southern site). 


\subsection{Physical and chemical properties}

\section{Water chemistry}

Hach Lang cuvette test kits were used to assay total and dissolved chemical oxygen demand (COD, disCOD, kit LCK 314), total and dissolved nitrogen (Ntot, disN, kit LCK 338), nitrite $\left(\mathrm{NO}_{2}{ }^{-}\right.$, kit LCK 342), nitrate $\left(\mathrm{NO}_{3}{ }^{-}\right.$, kit LCK 339) and total and dissolved phosphorus (Ptot, disP, kit LCK 350) with a Hach Titralab analyser and a Biogas Titration Manager, according to the manufacturer's instructions. If required, the samples were diluted to be within the measurement range. Samples of dissolved compounds were prepared by first filtering through 17-30 $\mu \mathrm{m}$ folded filters, then filtering though $0.7 \mu \mathrm{m}$ GF-F filters using a Büchner funnel. Ammonia $\left(\mathrm{NH}_{4}{ }^{+}\right)$concentration was determined using Nessler's reagent and phosphate $\left(\mathrm{PO}_{4}{ }^{3-}\right)$ concentration was determined using the ISO 6878 method. Total alkalinity (TA) was determined using the ISO 9963-1 method. Total suspended solids (TSS) were determined using the EN 872:2005 method. $\mathrm{pH}$ was measured using a double-junction $\mathrm{Ag} / \mathrm{AgCl} \mathrm{pH}$ electrode (Sentix 41, WTW, for the northern site and PHC 201, Hach, for the southern site).

\section{Carbon, nitrogen, phosphorus content in the biomass}

10-mL samples were filtered onto precombusted Whatman $\mathrm{GF} / \mathrm{F}$ filters and stored at $-80^{\circ} \mathrm{C}$ until analysis. The filters for particulate organic carbon (POC) and nitrogen (PON) analysis were dried at $60^{\circ} \mathrm{C}$ for $24 \mathrm{~h}$, pelleted and analyzed using an ANCA mass spectrometer (Europa Scientific). The filters for particulate organic phosphorus (POP) were processed by persulphate wet-oxidation in weak alkaline conditions to convert the organic phosphorus to phosphate [11]. The phosphate concentration was then determined using colorimetry [12] and modified by Koroleff [13]. 


\section{Chlorophyll a in the biomass}

$10 \mathrm{ml}$ samples for chlorophyll $a$ determination were filtrated onto $13 \mathrm{~mm}$ GF/F glassfiber filters. Filters were stored frozen at $-20^{\circ} \mathrm{C}$ until extraction with $5 \mathrm{ml}$ of absolute ethanol, consisting in a step of ultrasonication in ice bath followed by overnight extraction at $4^{\circ} \mathrm{C}$, filtration and absorbance measurement of the extract at 665 and $750 \mathrm{~nm}$ on a Hitachi U3000 zeroed with absolute ethanol. Chlorophyll $a$ concentration was calculated using Ritchie [14] equation:

$[\operatorname{chl} a]\left(\mu \mathrm{g} \cdot \mathrm{mL}^{-1}\right)=11,904 *(\mathrm{Abs} 665-\mathrm{Abs} 750) * \mathrm{v} / \mathrm{V}$

With $\mathrm{v}$ the volume of the extract $(\mathrm{ml}), \mathrm{V}$ the filtrated volume $(\mathrm{mL})$, Abs665 the absorbance read at $665 \mathrm{~nm}$ and Abs750 the absorbance read at $750 \mathrm{~nm}$.

\section{Light attenuation}

Discrete measurements of underwater light intensity were performed around zenithal time, in order to minimize bias (planar shape of the sensor, potential shading from surroundings structures and proportion of underwater light scattering), at 5 depths (sub-surface, 10, 20, 30 and $40 \mathrm{~cm}$ ) from 30/03/2017 to $21 / 05 / 2017$ using 5 waterproof light and temperature dataloggers (UA-002-64 HOBO, Onset). Despite their planar and wide spectrum sensor, these simple light loggers can reliably be a good alternative to cosine or scalar sensors as tested by Long et al [15] for relative intensity changes. Vertical attenuation coefficient for light was calculated from the irradiance exponential decrease with depth using Kirk [16] equation :

$\mathrm{E}_{\mathrm{d}}(\mathrm{z})=\mathrm{E}_{\mathrm{d}}(0) \exp \left(-\mathrm{Kd}^{*} \mathrm{z}\right)$

With $E_{d}(z)$ the light intensity at depth $z$ in lux, $E_{d}(0)$ the light intensity just below the surface in lux, $\mathrm{z}$ the depth in $\mathrm{m}$ and $\mathrm{K}_{\mathrm{d}}$ the vertical attenuation coefficient for light in $\mathrm{m}^{-1}$. 


\subsection{Biological properties}

\section{DNA extraction and bacterial $16 S$ rDNA sequencing}

Bacterial 16S rDNA was extracted from a $10-\mathrm{mL}$ sample filtered onto a $0.2 \mu \mathrm{m}$ membrane (PALL Supor® 200 PES), using the DNeasy PowerWater Kit (Qiagen) according to the manufacturer's instructions. The V4-V5 region of the $16 \mathrm{~S}$ rRNA gene was amplified over 30 amplification cycles at an annealing temperature of $65^{\circ} \mathrm{C}$, with the forward primer $\left(5^{\prime}\right.$ CTTTCCCTACACGACGCTCTTCCGATCTGTGYCAGCMGCCGCGGTA-3') and the reverse

primer (5'-GGAGTTCAGACGTGTGCTCTTCCGATCTCCCCGYCAATTCMTTTRAGT-3') with their respective linkers. The resulting products were purified and loaded onto the Illumina MiSeq cartridge for sequencing of paired 300 bp reads following the manufacturer's instructions (v3 chemistry). The Genotoul Lifescience Network Genome and Transcriptome Core Facility in Toulouse, France (get.genotoul.fr) carried out the library preparation and sequencing. A modified version of the standard operation procedure for MiSeq data [17] in Mothur version 1.35.0 [18] was used for alignment and as a taxonomic outline. Representative sequences of bacterial operational taxonomic units (OTUs) were identified at the $3 \%$ level using Mothur.

Quantification of total bacteria using quantitative real-time PCR

We used qPCR to quantify total bacteria with forward primer 5'ACTCCTACGGGAGGCAG-3', reverse primer 5'-GACTACCAGGGTATCTAATCC-3'" and TaqMan probe 5'Yakima Yellow-TGCCAGCAGCCGCGGTAATAC-TAMRA-3' to quantify total bacteria [19].

qPCR assays were carried out in triplicate using 96-well real-time PCR plates (Eppendorf) and a Mastercycler® ep Realplex (Eppendorf). The reaction mixture consisted of $12.5 \mu \mathrm{L}$ of 
EXPRESS SYBR GreenER qPCR mix with premixed ROX (Invitrogen), $5 \mu 1$ of DNA, $1 \mu \mathrm{L}$ of primers and $1 \mu \mathrm{L}$ of probe and water to a final volume of $25 \mu \mathrm{L}$. An initial incubation of $20 \mathrm{~s}$ at $95^{\circ} \mathrm{C}$ was followed by 40 cycles of denaturation $\left(15 \mathrm{~s}\right.$ at $\left.95^{\circ} \mathrm{C}\right)$ and hybridization/elongation $\left(60 \mathrm{~s}\right.$ at $\left.60^{\circ} \mathrm{C}\right)$. A standard curve was generated for each assay by using 10 -fold dilutions of pEX-A plasmids (Eurofins MWG Operon) containing the targeted gene sequences. Two different dilutions of each DNA sample were amplified and the calculated initial concentrations were compared to detect PCR inhibition. Inhibited PCR reactions produced lower values which were eliminated from the analysis. The quantification limit, defined using the lowest concentration of the linear range of the standard curve, was 10 copies per qPCR reaction for all qPCR systems. The amplification efficiency of the standard curves was between $98 \%$ and $100 \%$, with a regression coefficient value $\left(\mathrm{R}^{2}\right)$ systematically above 0.99 . Four copies of the $16 \mathrm{~S}$ rRNA gene were considered to be equivalent to a single cell [20]. A carbon conversion factor of $30 \mathrm{fgC}^{\mathrm{g}} \mathrm{cell}^{-1}$ was used to convert bacterial cell abundance into bacterial C biomass [21].

\section{Microalgal diversity, abundance, biovolume and carbon biomass}

To quantify the phytoplankton communities, $125-\mathrm{mL}$ water samples were fixed with formalin (2\% final concentration). The phytoplankton was enumerated in 1-mL subsamples in a sedimentation chamber $[22,23]$ using an IX70 inverted microscope (Olympus Life Science, Hamburg, Germany) equipped with a MoticamPro digital camera (Moticam, Hong Kong, China). Units (cells or colonies) were counted and sized in random fields under $40 \times$ magnification until at least 400 units of the dominant species had been enumerated [24]. The biovolume was calculated for each species according to Hillebrand et al. [25] and Sun and Liu [26] and converted into carbon biomass (C Biomass) using a conversion factor of $220 \mathrm{fg} \mathrm{C}$ $\mu \mathrm{m}^{3}[27]$. 
Protozoan and metazoan diversity, abundance, biovolume and carbon biomass

For protozoan and metazoan abundance and identification, 2-L water samples were filtered through a $100 \mu \mathrm{m}$ filter and then through a $35 \mu \mathrm{m}$ filter to separate 35 to $100 \mu \mathrm{m}$ and $>100$ $\mu \mathrm{m}$ size fractions, which were then stored in neutralized formalin (4\% final concentration). The protozoan and metazoan taxa in the 35 to $100 \mu \mathrm{m}$ fraction were identified, sized and enumerated using an Olympus AX70 dissecting microscope with a hemocytometer. Protozoan and metazoan taxa in the $>100 \mu \mathrm{m}$ fraction were identified and enumerated using a Olympus Stereomicroscope SZX7 with a Bogorov counting chamber. Conversion factors for carbon biomass ( $\mathrm{C}$ biomass) were taken from the literature for ciliates, rotifers and nematodes [28, $29,30]$.

\subsection{Statistical tests}

A t test was used to test differences between geographical sites for each variable of the dataset consisting of the environmental factors (daily incident light dose, water temperature, rainfall), the microbial biomass (concentration of chlorophyll $a$ as a proxy of algal biomass and bacterial biomass), and the removal efficiencies (COD, $\mathrm{NH}_{4}{ }^{+}, \mathrm{PO}_{4}{ }^{3-}$ ) measured weekly $(\mathrm{n}=35)$, from the period when microalgae biomass (chlorophyll $a$ ) was reached the maximal value $\left(4 \mathrm{mg} \mathrm{L}^{-1}\right)$. A correlation-based principal component analysis (PCA) was applied for this weekly samples dataset in order to detect significant correlations between the environmental and microbial variables and the removal efficiencies measured in the two geographical sites after the period of the rapid microalgae growth. All the statistical tests were performed with PAST version 3.22. [31]. 
3. Results

\subsection{Climatic conditions}

The maximum incident light and daily dose received at both sites ranged from 500 to 2000 $\mu \mathrm{E} \cdot \mathrm{m}^{-2} \cdot \mathrm{s}^{-1}$ and from 2 to $57 \mathrm{mE} \cdot \mathrm{m}^{-2} \cdot \mathrm{d}^{-1}$, respectively, with the lowest values in winter (S1Figure). The water temperature ranged between $10-15^{\circ} \mathrm{C}$ and $30^{\circ} \mathrm{C}$ in the HRAPs with the lowest values in winter and highest values in summer (S1-Figure). In general, the water temperature was about $5^{\circ} \mathrm{C}$ higher than the air temperature (data not shown). The highest rain values were occasionally measured in August in the Northern site and in October $(57 \mathrm{~mm})$ and in October $(52 \mathrm{~mm})$ in the southern site. The proportion of days without rainfall during the studied periods was $33 \%$ and $76 \%$ for northern and southern site, respectively (S1Figure).

\subsection{Chemical and biological properties}

Over the study period, the characteristics of the wastewater were similar for the two sites, but there were some significant differences (Table 1). The average ratio of ammonium to phosphate (mol:mol) was significantly higher in the northern wastewater (44:1) than in the southern wastewater (34:1). However, the phosphorus contents (dissolved and total) were much higher at the northern site indicating a higher contribution of organic phosphorus in the northern wastewater than in the southern wastewater (Table 1) where the wastewater is partially diluted with rainwater drainage. 

Table 1: Chemical characteristics of wastewaters effluent for the northern $(\mathrm{N})$ and southern $(\mathrm{S})$ sites. COD: Chemical Oxygen Demand, disCOD: dissolved COD, $\mathrm{N}-\mathrm{NH}_{4}{ }^{+}$: Ammonium concentrations, $\mathrm{N}_{-} \mathrm{NO}_{2}{ }^{-}$: Nitrite concentrations, $\mathrm{N}_{-} \mathrm{NO}_{3}-$ : Nitrate concentrations, Ptot: Total Phosphorus, disP: dissolved $\mathrm{P}, \mathrm{P}_{-} \mathrm{PO}_{4}{ }^{3-}$ : Phosphate concentrations, TA: Total alkalinity, TSS: Total suspended solids, n: number of measurements

\begin{tabular}{|c|c|c|c|c|c|c|c|c|c|c|}
\hline Properties & Sites & mean & median & std dev & std err & $\begin{array}{c}95 \% \text { Int. } \\
\text { Conf. }\end{array}$ & $\begin{array}{c}99 \% \text { Int. } \\
\text { Conf. }\end{array}$ & $\mathrm{n}$ & $\min$ & $\max$ \\
\hline \multirow{2}{*}{$\mathrm{COD}\left(\mathrm{mg} \cdot \mathrm{L}^{-1}\right)$} & $\mathrm{N}$ & 902 & 798 & 404 & 44 & 87 & 115 & 86 & 267 & 2263 \\
\hline & $\mathrm{S}$ & 618 & 610 & 155 & 18 & 35 & 47 & 77 & 328 & 1070 \\
\hline \multirow{2}{*}{$\operatorname{disCOD}\left(\mathrm{mg} \cdot \mathrm{L}^{-1}\right)$} & $\mathrm{N}$ & 348 & 356 & 68 & 7 & 15 & 19 & 86 & 114 & 528 \\
\hline & $\mathrm{S}$ & 247 & 248 & 52 & 6 & 12 & 16 & 77 & 135 & 375 \\
\hline \multirow{2}{*}{$\mathrm{N}-\mathrm{NH}_{4}{ }^{+}\left(\mathrm{mg} \cdot \mathrm{L}^{-1}\right)$} & $\mathrm{N}$ & 63 & 63 & 11 & 1 & 2 & 3 & 86 & 34 & 98 \\
\hline & $\mathrm{S}$ & 54 & 54 & 8 & 1 & 2 & 2 & 77 & 34 & 91 \\
\hline \multirow{2}{*}{$\mathrm{N}-\mathrm{NO}_{2}^{-}\left(\mathrm{mg} \cdot \mathrm{L}^{-1}\right)$} & $\mathrm{N}$ & 0.09 & 0.07 & 0.09 & 0.01 & 0.02 & 0.03 & 86 & 0.00 & 0.66 \\
\hline & $\mathrm{S}$ & 0.04 & 0.05 & 0.03 & 0.00 & 0.01 & 0.01 & 77 & 0.00 & 0.09 \\
\hline \multirow{2}{*}{$\mathrm{N}-\mathrm{NO}_{3}^{-}\left(\mathrm{mg} \cdot \mathrm{L}^{-1}\right)$} & $\mathrm{N}$ & 0.62 & 0.57 & 0.23 & 0.02 & 0.05 & 0.07 & 86 & 0.01 & 1.35 \\
\hline & $\mathrm{S}$ & 0.16 & 0.00 & 0.19 & 0.02 & 0.04 & 0.06 & 77 & 0.00 & 0.50 \\
\hline \multirow{2}{*}{ Ptot $\left(\mathrm{mg} . \mathrm{L}^{-1}\right)$} & $\mathrm{N}$ & 11.1 & 10.3 & 3.5 & 0.4 & 0.8 & 1.0 & 86 & 4.8 & 22.6 \\
\hline & $\mathrm{S}$ & 7.4 & 7.2 & 1.3 & 0.2 & 0.3 & 0.4 & 77 & 4.5 & 11.0 \\
\hline \multirow{2}{*}{$\operatorname{dis} \mathrm{P}\left(\mathrm{mg} \cdot \mathrm{L}^{-1}\right)$} & $\mathrm{N}$ & 6.4 & 6.4 & 0.9 & 0.1 & 0.2 & 0.3 & 86 & 3.5 & 8.4 \\
\hline & $\mathrm{S}$ & 4.3 & 4.3 & 0.8 & 0.1 & 0.2 & 0.2 & 77 & 2.5 & 6.0 \\
\hline \multirow{2}{*}{$\mathrm{P}-\mathrm{PO}_{4}{ }^{3-}\left(\mathrm{mg} \cdot \mathrm{L}^{-1}\right)$} & $\mathrm{N}$ & 3.1 & 3.2 & 0.5 & 0.1 & 0.1 & 0.1 & 86 & 1.7 & 4.5 \\
\hline & $S$ & 3.5 & 3.6 & 0.6 & 0.1 & 0.1 & 0.2 & 77 & 2.1 & 4.8 \\
\hline \multirow{2}{*}{$\mathrm{pH}$} & $\mathrm{N}$ & 7.6 & 7.6 & 0.2 & 0.0 & 0.0 & 0.1 & 86 & 6.7 & 8.0 \\
\hline & $\mathrm{S}$ & 7.9 & 7.9 & 0.2 & 0.0 & 0.1 & 0.1 & 77 & 7.5 & 8.7 \\
\hline \multirow{2}{*}{$\mathrm{TA}\left({ }^{\circ} \mathrm{F}\right)$} & $\mathrm{N}$ & 52 & 53 & 4.5 & 0.5 & 1.0 & 1.3 & 86 & 33.7 & 62.9 \\
\hline & $\mathrm{S}$ & 44 & 44 & 3.3 & 0.4 & 0.7 & 1.0 & 77 & 28.8 & 53.5 \\
\hline \multirow{2}{*}{ TSS (mg.L $\left.{ }^{-1}\right)$} & $\mathrm{N}$ & 353 & 306 & 179 & 19 & 38 & 51 & 86 & 108 & 904 \\
\hline & $\mathrm{S}$ & 320 & 292 & 140 & 16 & 32 & 42 & 77 & 44 & 768 \\
\hline
\end{tabular}



The comparison of the concentrations of $\mathrm{NH}_{4}{ }^{+}, \mathrm{PO}_{4}{ }^{3-}$ and dissolved COD in the wastewater and in the HRAPs showed that the removal efficiency for nitrogen, phosphorus and organic compounds was very variable. In the northern HRAP, $50 \%$ of $\mathrm{PO}_{4}{ }^{3-}$ and more than $80 \%$ of dissolved $\mathrm{COD}$ and $\mathrm{NH}_{4}{ }^{+}$were removed about one month after start-up (Figure 1A). The $\mathrm{PO}_{4}{ }^{3-}$ removal efficiency decreased when the water temperature dropped from $27^{\circ} \mathrm{C}$ to $18^{\circ} \mathrm{C}$ and the daily incident light dose fell below $30 \mathrm{mE} \cdot \mathrm{m}^{-2} \cdot \mathrm{d}^{-1}$ at the end of August and beginning of September (S1-Figure). In the southern HRAP, an average of $90 \%$ of $\mathrm{NH}_{4}{ }^{+}$and of $50 \%$ of dissolved $\mathrm{COD}$ and $\mathrm{PO}_{4}{ }^{3-}$ were removed within three months (Figure 1B). However, the removal efficiency of $\mathrm{NH}_{4}{ }^{+}$started to decrease from the beginning of September 2016 (Figure 1B). 


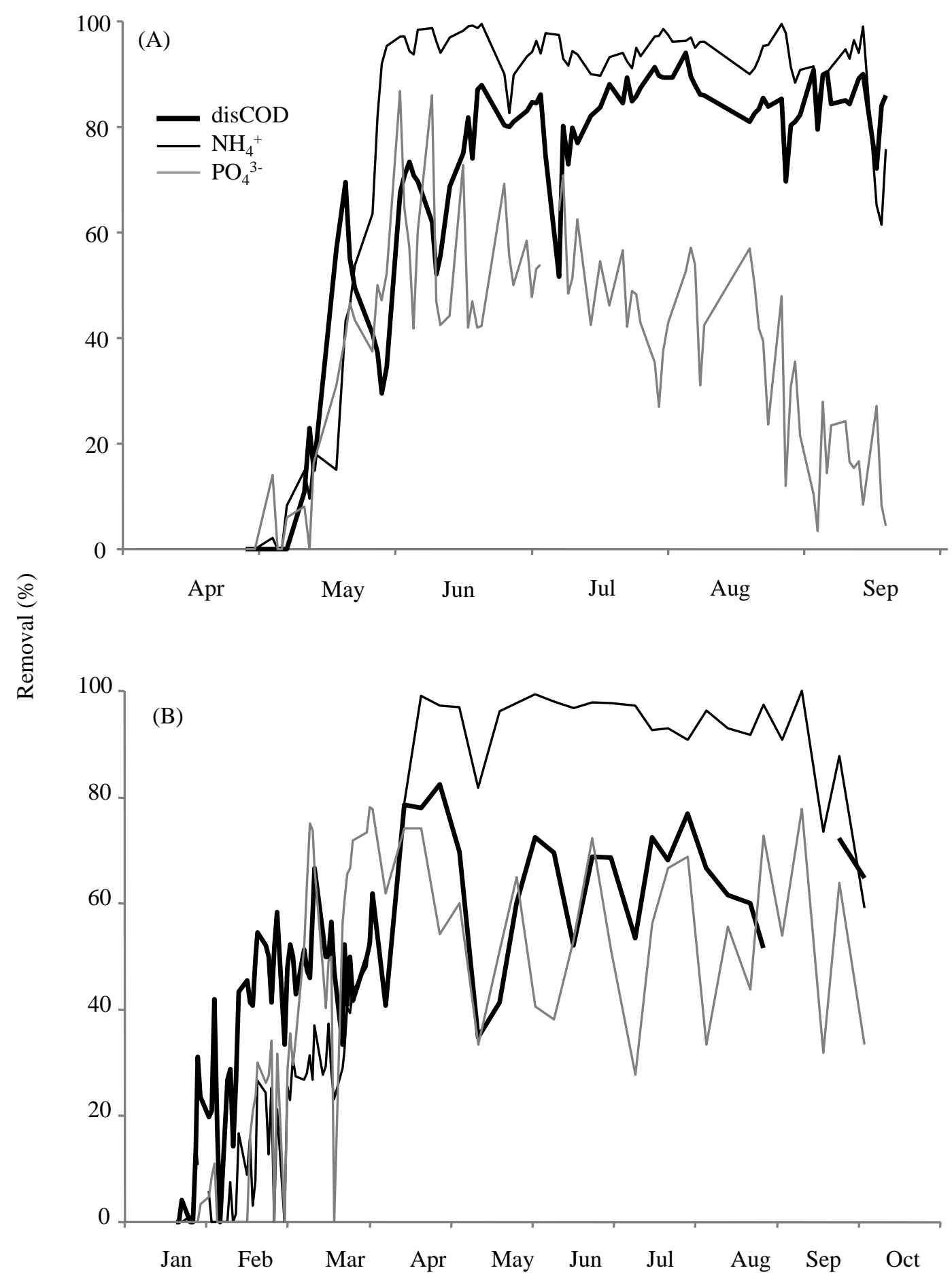

Figure 1: Removal (in \%) of the dissolved COD (disCOD), $\mathrm{PO}_{4}{ }^{3-}$, and $\mathrm{NH}_{4}{ }^{+}$in the northern (A) and southern (B) HRAPs. Removal was calculated as the difference between the concentrations in the wastewater and in the HRAP expressed as the $\%$ of the concentration in the wastewater. 
For both HRAPs (Figure 2), at the end of the initial peak in $\mathrm{pH}(>9)$, the chlorophyll $a$ concentration reached values equivalent or greater than $4 \mathrm{mg} \cdot \mathrm{L}^{-1}$ (end of May -beginning of June).

As soon as the microalgal biomass started to grow in both HRAPs, the $\mathrm{C}, \mathrm{N}$ and $\mathrm{P}$ biomass dynamics were very similar and followed the Chlorophyll $a$ concentrations (S2Table). During the period of microalgal growth, the $\mathrm{C}: \mathrm{N}: \mathrm{P}$ molar ratio of biomass averaged 100:12:1. 

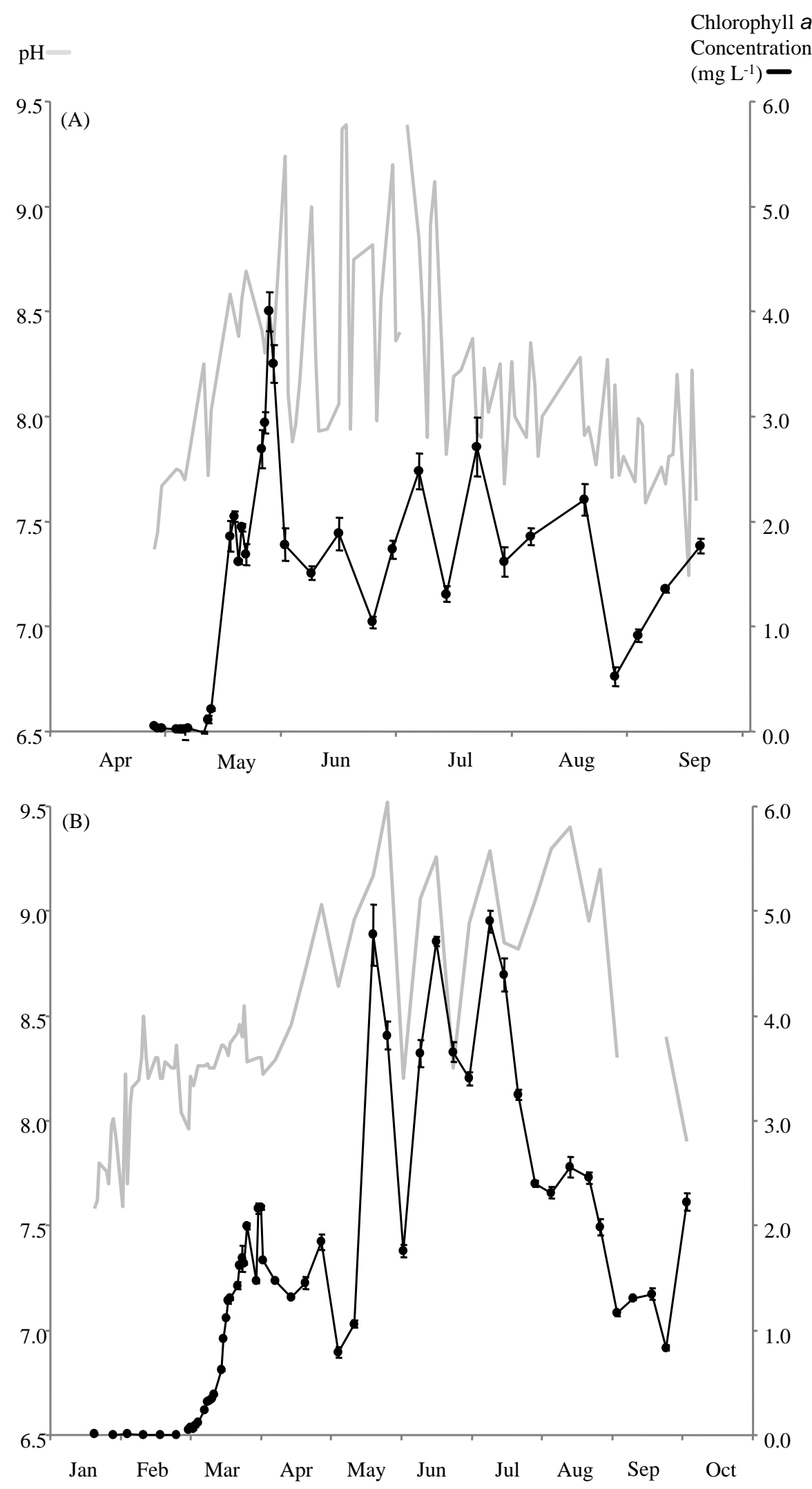

Figure 2: $\mathrm{pH}$ and Chlorophyll $a$ concentration (mean and standard deviation from triplicate samples) as a function of time in (A) the northern HRAP and (B) the southern HRAP. 


\subsection{Heterotrophic bacterial dynamics}

In the northern HRAP, the bacterial abundance increased with a peak of $4 \times 10^{12}$ cells. $\mathrm{L}^{-1}$ on June $26^{\text {th }} 2015$, two months after the beginning of the experiment (S3-Figure). In the southern HRAP, the abundances were significantly lower (t-test, $p<0.001$ ) and varied around $2.6 \times 10^{11}$ (S3-Figure). In the northern HRAP, the bacterial community was initially dominated by the classes Bacteroidia, Bacilli, Clostridia, $\beta$ - and $\gamma$-Proteobacteria. The proportion of Bacteroidia, Bacilli, and Clostridia decreased rapidly within the first month, in favour of Sphingobacteriia, and $\alpha-, \beta$ - and $\gamma$-Proteobacteria and Cytophagia by the end of the studied period (S3-Figure). In the southern HRAP, the pattern was similar but with a much higher proportion of $\beta$-Proteobacteria (ca. 40\%) throughout the study period (S3-Figure). Regarding the potential nitrifying bacteria such as Nitrosomas, they started to develop when the algal biomass was growing, in May and March in the northern and the southern HRAP respectively (Figure 3). Lower relative abundance of Nitrosomas was observed during summer in the southern HRAP (Figure 3B). Numerous genera of bacteria may contain heterotrophic denitrifying bacteria, although not all heterotrophic denitrifiers can perform complete denitrification. When focussing on genera of potential denitrifying species observed in activated sludge [32] and present in both HRAPs (Acinetobacter, Achromobacter, Alcalignes, Bacillus, Corynebacterium, Haliangium, Dechloromonas, Flavobacterium, Rhizobium, Pseudomonas, Thauera, Thermomonas), a peak of denitrifiers was observed when the algal biomass started to grow in both HRAPs (Figure 3). Afterwards, their relative abundance was decreasing and remained low $(<3 \%)$ except when the algal biomass suddenly decreased (May, August and September in the southern HRAP). 

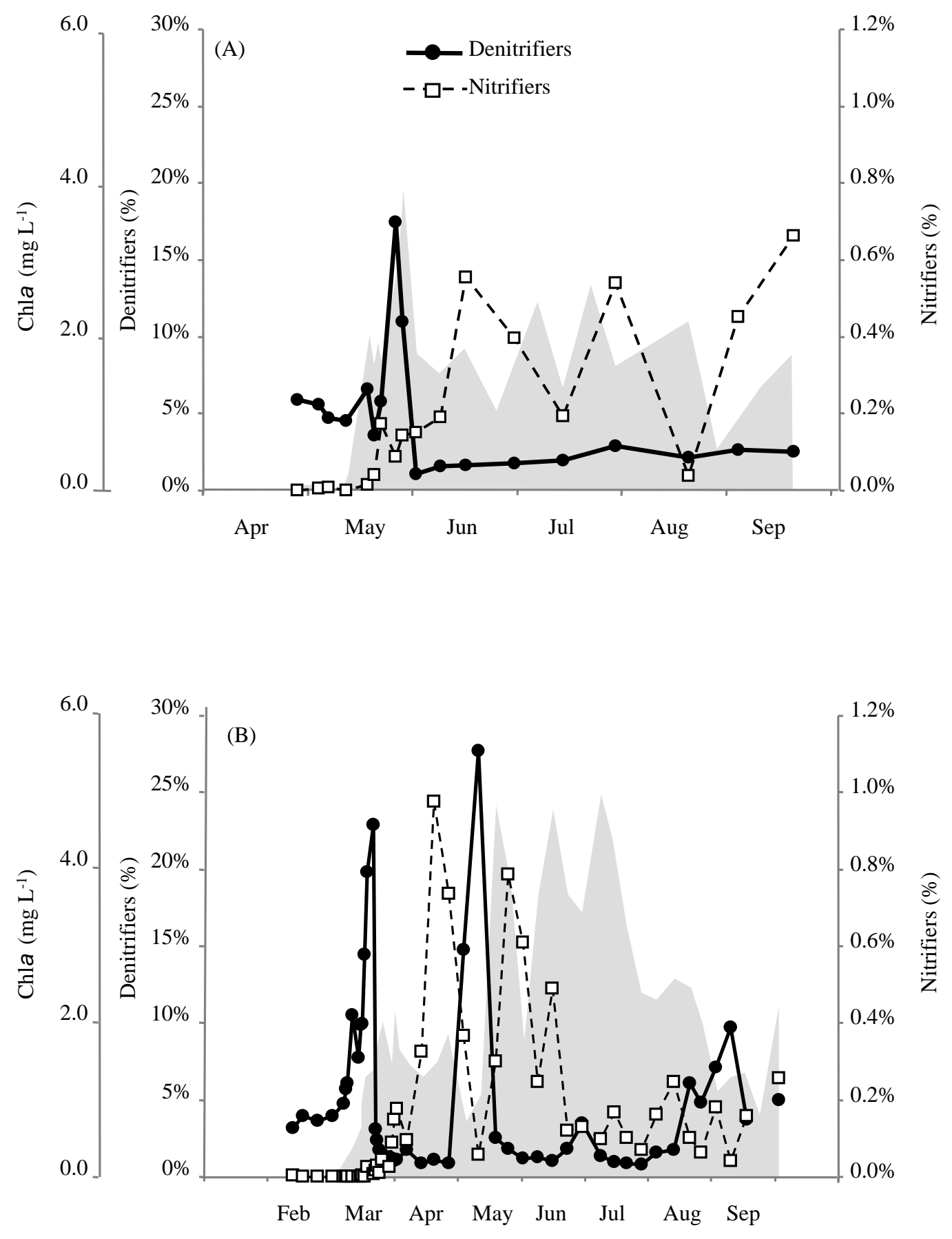

Figure 3: The relative abundance of bacterial OTUs (\%) corresponding to potential nitrifying and denitrifying genera (see text) present in both HRAPs, as a function of time in (A) the northern HRAP and (B) the southern HRAP. Chlorophyll $a$ concentrations were reported in shaded background. 


\subsection{Microalgal and cyanobacterial diversity}

Of the 33 taxa identified by microscopy, 16 taxa were common to both HRAPs with the main taxa being cyanobacteria or chlorophytes. It should be noted that more diatom taxa were found in the southern HRAP (S4-Table). Some species, mainly some Oscillatoriales (cyanobacteria), were only found in the wastewater in the southern HRAP and a green microalgae (Scenedesmus acuminatus) was only found in the northern HRAP. During the microalgal growth period, chlorophytes generally accounted for more than $70 \%$ of the total abundance and biovolume in both HRAPs with a maximum biomass of 40-50 mg.L ${ }^{-1}$ (Figure 4). During this initial period of microalgal growth, a succession of two chlorophyte species (representing more than $80 \%$ of total chlorophytes) was observed in both HRAPs (S3-Table) with the initial growth of Chlorella sp up to a maximum of $3.9 \times 10^{9}$ cell. $\mathrm{L}^{-1}$, followed by $S$. acuminatus ( $\max 1.7 \times 10^{9}$ cell. $\left.\mathrm{L}^{-1}\right)$. 


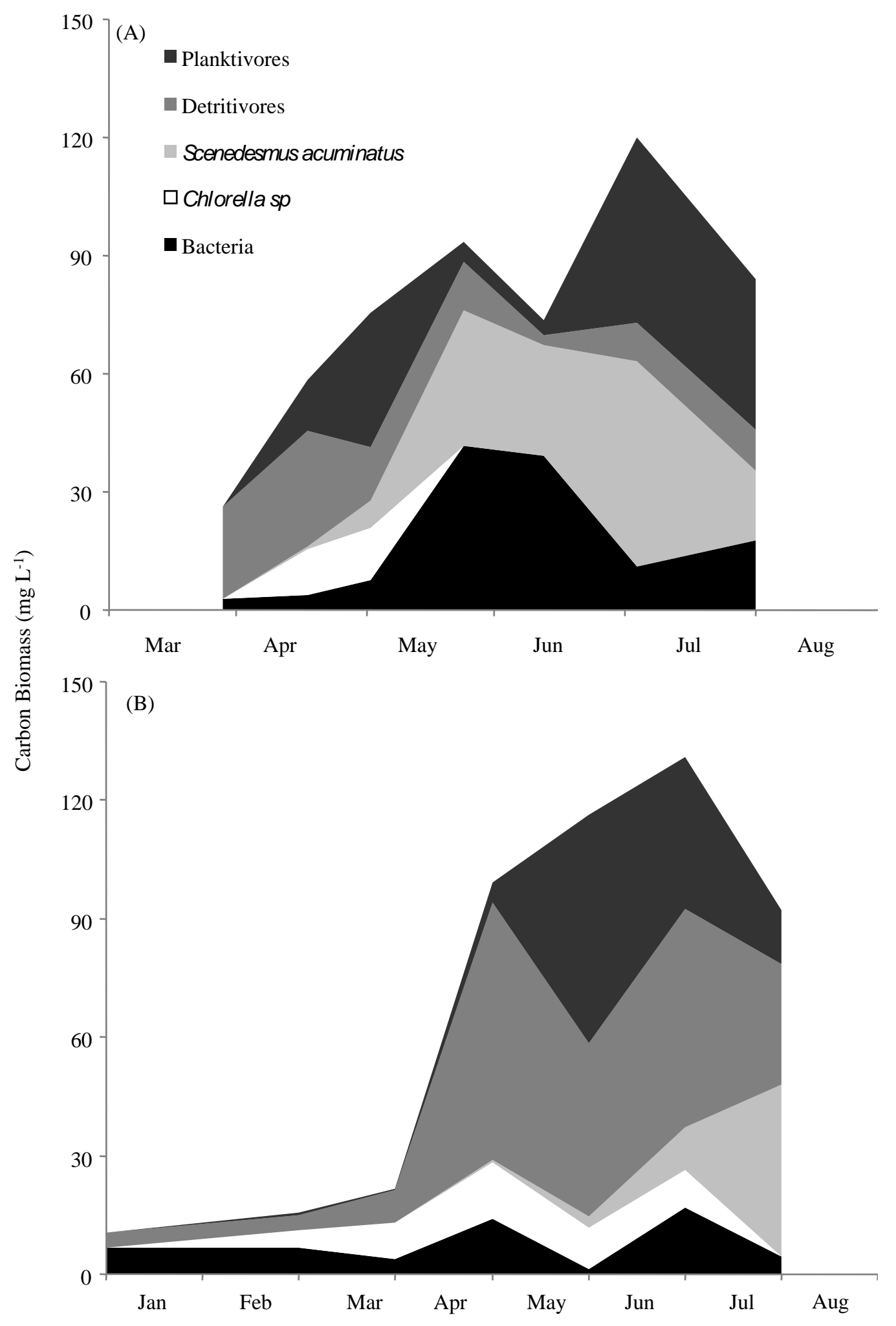

Figure 4: The $\mathrm{C}$ biomass for bacteria, microalgae, protozoans and metazoans in the northern and southern HRAPs during the study period. The abundances were converted into C biomass using conversion factors taken from literature. 


\subsection{Growth of protozoans and metazoans}

Rhizopoda ( 1 to $6 \times 10^{5}$ ind. $\mathrm{L}^{-1}$ ) were the main group of large metazoans present in the wastewater for both HRAPs before the microalgae grew (S5-Table). The succession of different predator groups during the initial start-up period was quite similar in the two HRAPs. After the initial rapid growth of Rhizopoda to a peak biomass of $30-65 \mathrm{mg} . \mathrm{L}^{-1}$, sessile and free-swimming ciliates (protozoans) then grew to a peak biomass greater than 40 mg.L $\mathrm{L}^{-1}$, followed by small $(<100 \mu \mathrm{m})$ rotifers (S5-Table). These were followed by larger $(>100 \mu \mathrm{m})$ metazoans with similar abundances in the two HRAPs, with nematodes being the most abundant and rotifers the next most abundant (S5-Table).

\subsection{Dynamics of biomass compartments}

Detrivores (Rhizopods and Nematods) and bacteria dominated the total $\mathrm{C}$ biomass at the beginning of the study period, averaging $56 \pm 23 \%$ until the microalgae became dominant in the two HRAPs (Figure 4). There was a clear microalgal succession in both HRAPs with the rapid growth of first Chlorella sp and then Scenedesmus acuminatus with both contributing up to $45-49 \%$ of the total $\mathrm{C}$ biomass. The microalgal growth was closely followed by the growth of planktivores (i.e. ciliates and rotifers) that contributed up to about $50 \%$ of total C biomass (Figure 4).

\subsection{Turbidity clearance before microalgal growth}

The second experimental run on the southern HRAP in spring 2017, when light attenuation was recorded within the HRAP, showed a reduction of light attenuation simultaneously with a strong increase of in dissolved COD removal during the first 15 days of the experiment (Figure 5). The microalgal biomass started to grow when the vertical attenuation coefficient for light fell below $30 \mathrm{~m}^{-1}$ (Figure 5). As the light attenuation decreased to $15 \mathrm{~m}^{-1}$, the 
dissolved COD removal reached an average of $75 \%$. The peak chlorophyll $a$ concentration (6 mg. $\mathrm{L}^{-1}$ ) was reached one month after the beginning of this new experimental run (Figure 5).

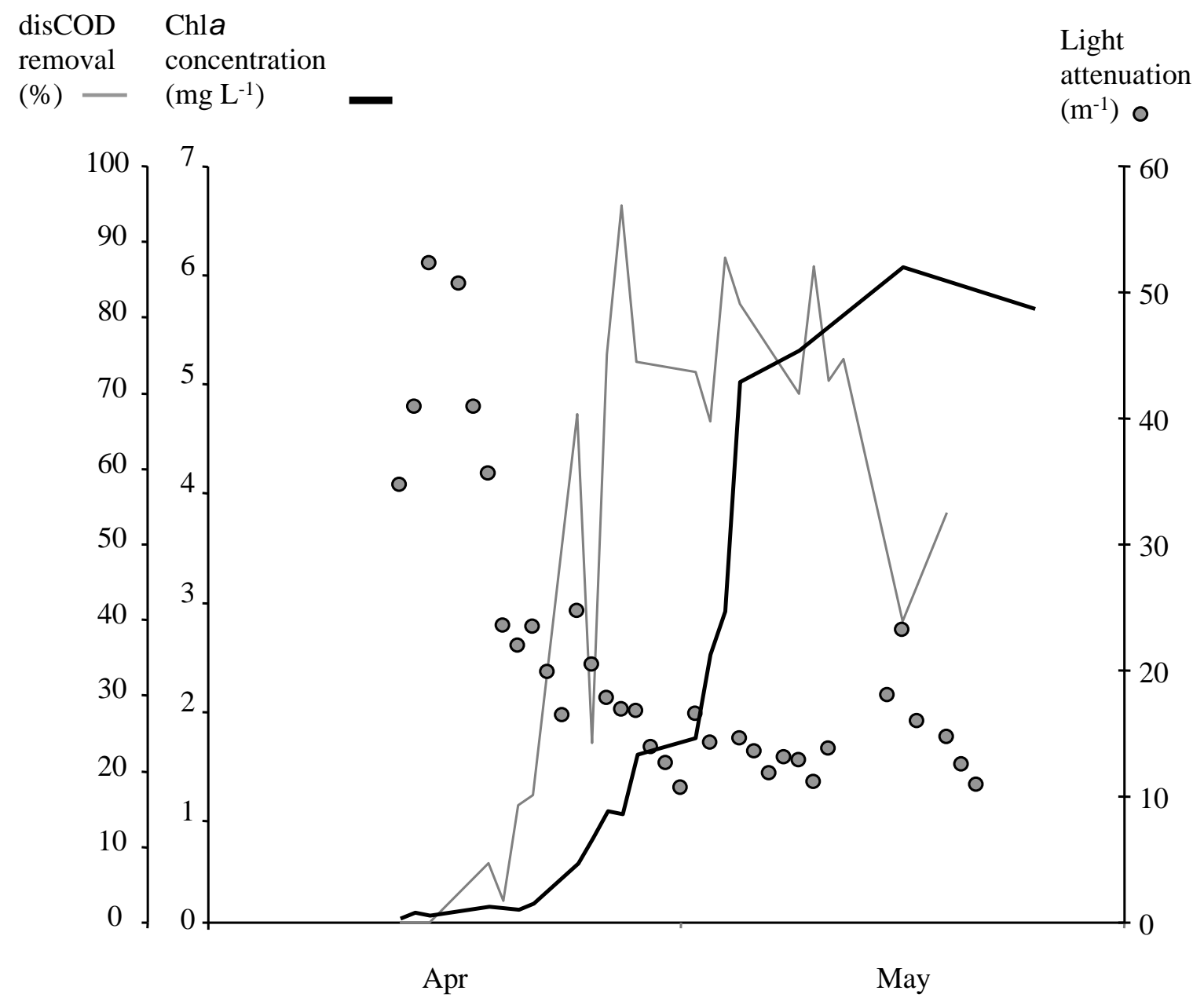

Figure 5: The light attenuation, dissolved COD (disCOD) removal and microalgal biomass (Chlorophyll $a$ concentration) as a function of time in the southern HRAP in Spring 2017. disCOD removal was calculated as the difference between the disCOD in the wastewater and the disCOD in the HRAP expressed as the $\%$ of the disCOD in the wastewater.

\subsection{Correlations between climate, microbial biomass and removal efficiency}

Significant differences ( $\mathrm{t}$ test, $p<0.05, \mathrm{n}=35$ ) between the two geographical locations were reported for environmental and microbial data measured weekly during the period following the initial algal growth phase. The southern site was characterised by higher average of water 
temperature, daily incident light dose and microalgal biomass (chlorophyll $a$ ) than southern site, characterised by higher average of bacterial biomass. No significant differences (t-test, $p$ $>0.05, \mathrm{n}=35$ ) between the two geographical locations were measured for rainfall, and disCOD, $\mathrm{NH}_{4}{ }^{+}$and $\mathrm{PO}_{4}{ }^{3-}$ removal efficiencies. During this period, following the start-up phase, the first axis (31\% of table inertia) opposed i) high values of $\mathrm{NH}_{4}{ }^{+}$and $\mathrm{PO}_{4}{ }^{3-}$ removal efficiencies associated to the high values of water temperature, daily incident light dose and microalgae biomass, to ii) the high rainfall values (Figure 6). Interestingly, both the first axis and the second axis (21\%) opposed i) the high values of bacteria biomass and disCOD removal efficiency, to ii) the high values of microalgal biomass (Figure 6). 


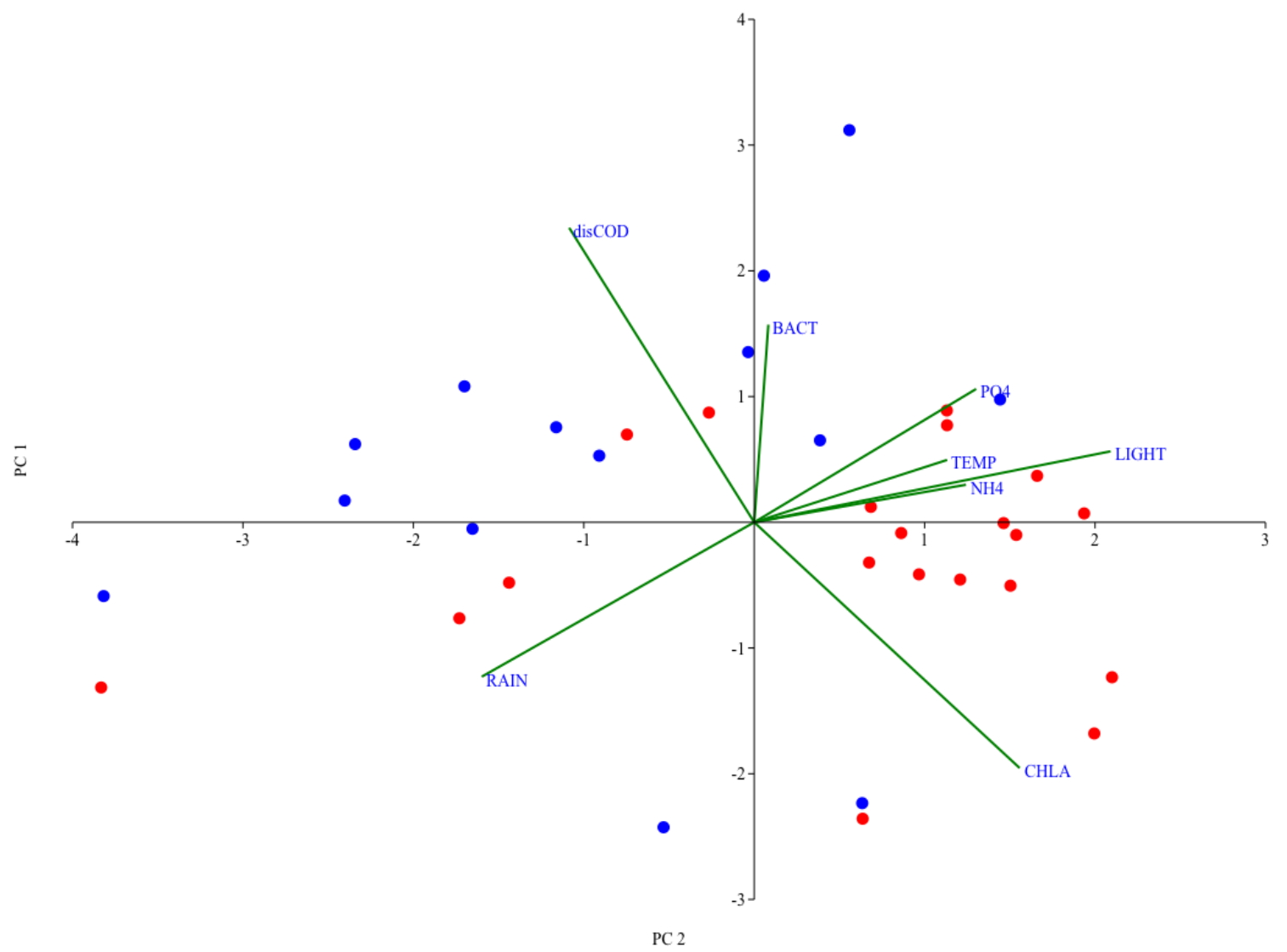

Figure 6: A 35-sample 2D-PCA biplots of principal component $1(31 \%)$ and $2(21 \%)$ based on correlation coefficients of environmental (temperature: TEMP, daily incident light dose: LIGHT, rainfall: RAIN), microbial biomass (bacteria: BAC, microalgae: CHLA) and removal efficiency (disCOD, $\mathrm{PO}_{4}{ }^{3-}, \mathrm{NH}_{4}{ }^{+}$) variables measured weekly in northern (blue dots) and southern (red dots) sites during the period following the initial rapid algal growth. 


\section{Discussion}

\subsection{Biological water clarification during the start-up phase}

During the start-up period there was a dramatic reduction in the organic matter content (removal of $80 \%$ of dissolved COD: disCOD) on both study sites. This rapid reduction is likely due to the presence of a well-adapted bacterial and protozoan (detritivores) community already present in the wastewater (the bacteria classes Bacteroidia, Bacilli and Clostridia, amoebozoa and nematodes) which broke down the organic matter rapidly. The removal of this organic matter led to an increase in light availability within the HRAP, which benefits fastgrowing autotrophic organisms such as Chlorella sp. The replacement of Chlorella sp. by Scenedesmus acuminatus was also observed in another study of using HRAP to treat municipal wastewater at a similar latitude [9]. Such a succession may be explained by i) a strong grazing pressure on Chlorella sp. by ciliates growing rapidly in spring and ii) $S$. acuminatus having a greater resistance to grazing pressure (colony formation, presence of spicules). During this initial period of microalgal growth, the bacterial community composition shifted with a reduction in classes typical of wastewater, such as Firmicutes [33], but with the increase of nitrifying bacteria such as Nitrosomas (Figure 3). This is probably due to the dramatic change in the conditions such as high concentrations of oxygen and elevated $\mathrm{pH}$ as a consequence of the rapid growth of microalgae in the raceway.

The $\mathrm{NH}_{4}{ }^{+}, \mathrm{PO}_{4}{ }^{3-}$ and disCOD (> 70\%) removal maxima were reached in about a month in the northern HRAP starting in April 2015 and within three months in the southern HRAP starting in January 2016. This difference is due to the difference in ambient temperature at start-up, in spring at the northern site but in winter at the southern site. This is supported by the rapid dissolved COD removal (within one month) observed at the southern site during the second experimental run starting in April 2017. Despite some differences 
observed in the chemical characteristics of the wastewater of the two HRAPs, different latitudes and different climates, disCOD (200-360 mg. $\left.\mathrm{L}^{-1}\right)$, phosphate (2-3 mg. $\left.\mathrm{L}^{-1}\right)$, and ammonia (40-60 mg. $\mathrm{L}^{-1}$ ) were all removed efficiently within a month, during spring season. Simultaneously, microalgae concentration increased to about 4-5 mg Chla. $\mathrm{L}^{-1}$ in about two weeks time in both locations in spring, corresponding to about one cell division every two days. Very few studies have focussed on the start-up period of wastewater treatment in HRAPs, and none of these have taken the frequent measurements required to measure growth rates. Our results are close to those obtained under laboratory condition, showing that both Chlorella sorokiniana and Scenedesmus obliquus could individually grow in $100 \%$ urban wastewater, reaching a maximum biomass in 15 days (one cell division every 2-3 days) and removing more than $70 \%$ of $\mathrm{COD}, \mathrm{NH}_{4}{ }^{+}$and $\mathrm{PO}_{4}{ }^{3-}$ [34]. We therefore suggest that in temperate climates during the growing season, with the initial help of detrivores and bacteria for a rapid water clarification, two weeks are required for microalgae to grow naturally in wastewater without start-up inoculation, and remove most disCOD, $\mathrm{NH}_{4}{ }^{+}$and $\mathrm{PO}_{4}{ }^{3}$.

\subsection{Influence of microbial $\mathrm{N}$ exhaustion on P removal}

For both HRAPs, the $\mathrm{PO}_{4}{ }^{3-}$ removal was on average $50 \%$ and highly variable throughout the study periods, decreasing to less than $10 \%$ in September at the northern site. Given the molar $\mathrm{N}: \mathrm{P}$ ratio of the biomass $(12 \pm 3)$ produced in both HRAPs and the molar $\mathrm{NH}_{4}{ }^{+}: \mathrm{PO}_{4}{ }^{3-}$ ratio of the wastewater (greater than 30), phosphate should have been the main limiting factor for microalgal growth. But the almost complete removal of $\mathrm{NH}_{4}{ }^{+}$and only partial removal of $\mathrm{PO}_{4}{ }^{3-}$ in both HRAPs, would suggest an overconsumption of $\mathrm{NH}_{4}{ }^{+}$compared to $\mathrm{PO}_{4}{ }^{3-}$, making $\mathrm{N}$ the main resource controlling the microalgal biomass production. The $\mathrm{N}$ biomass produced in both HRAPs was much lower than the $\mathrm{NH}_{4}{ }^{+}$removed (S6-Figure). Therefore, a large fraction of the $\mathrm{NH}_{4}{ }^{+}$consumption $(>50 \%)$ was not converted into measurable $\mathrm{N}$ biomass, 
suggesting high $\mathrm{N}$ losses. A significant release of nitrogen as dissolved organic compounds by microalgae or bacteria was unlikely as no accumulation of dissolved organic nitrogen (the difference between dis $\mathrm{N}$ and inorganic $\mathrm{N}$ forms) was observed in the HRAPs (data not shown). A large $\mathrm{N}$ loss through $\mathrm{NH}_{3}$ stripping was also unlikely because the $\mathrm{NH}_{3}$ contribution to $\mathrm{NH}_{4}{ }^{+}$was between 5 and $30 \%$ according to the $\mathrm{pH}$ (between 8 and 9) and the very high $\mathrm{NH}_{4}{ }^{+}$solubility in water makes $\mathrm{NH}_{3}$ stripping difficult without intense aerosolization. The biological release of $\mathrm{N}$-compounds with a weaker solubility in water such as $\mathrm{N}_{2}$ generally occurs through bacteria activity under anoxic or hypoxic conditions [35]. The presence of first $\mathrm{NO}_{2}^{-}$and then $\mathrm{NO}_{3}^{-}$production in both HRAPs (S6-Figure) are indicative of nitrification processes through the oxidation of $\mathrm{NH}_{4}{ }^{+}$by nitrifying bacteria. This is supported by the increasing relative abundance of nitrifying species such as Nitrosomas when microalgae started to grow in both HRAPs. The stimulation of nitrification activity due to increased oxygen-derived photosynthesis has been reported [36, 37], although some studies have reported potential nitrification inhibition in the presence of microalgae [38]. The succession of highly oxygenated conditions during daylight and the anoxic or hypoxic conditions during the night, together with the continuous supply of high $\mathrm{NH}_{4}{ }^{+}$seems to favour the oxidation of $\mathrm{NH}_{4}{ }^{+}$into $\mathrm{N}_{2}$. Occasional peaks of potential denitrifying species were reported in both HRAPs, supporting that denitrification might have occurred during the algal growth period. In contrast, the maximum values of the phosphorus content of the biomass produced in the HRAPs were close to the $\mathrm{PO}_{4}{ }^{3-}$ concentrations removed (S6-Figure). This suggests that $\mathrm{PO}_{4}{ }^{3-}$ was mainly consumed by microalgae in both HRAPs, but $\mathrm{PO}_{4}{ }^{3-}$ microalgal consumption was probably limited by the low $\mathrm{NH}_{4}{ }^{+}$availability due to the activity of nitrifyers/denitrifyers converting $\mathrm{NH}_{4}{ }^{+}$as $\mathrm{N}_{2}$. This is supported by the higher $\mathrm{PO}_{4}{ }^{3-}$ removal rates observed at the end of summer in southern HRAP as compared to the northern HRAP, when the relative abundance of potential nitrifying species was very low. 


\subsection{Critical role of microbial interactions in the wastewater treatment efficiency}

After the rapid development of microalgae biomass during the start-up phase, the highest $\mathrm{NH}_{4}{ }^{+}$and $\mathrm{PO}_{4}{ }^{3-}$ removal efficiencies were related to the high activity of microalgae under elevated water temperature and daily incident light dose, but low rainfall. This clearly highlights the direct influence of environmental conditions on the $\mathrm{N}$ and $\mathrm{P}$ removal efficiencies. Although the average of microalgae biomass was significantly higher in southern site than in northern site because of warmer and higher light conditions, similar $\mathrm{NH}_{4}^{+}$and $\mathrm{PO}_{4}{ }^{3-}$ removal efficiencies were measured in both sites. However, very low $\mathrm{PO}_{4}{ }^{3-}$ removal efficiencies were reported in northern site at the end of the study (Figure 1A). Such low $\mathrm{PO}_{4}{ }^{3-}$ removal was attributed to the microalgal growth conditions becoming less favourable, with low daily incident light dose, together with a strong $\mathrm{NH}_{4}^{+}$competition with nitrifying bacteria. In addition to low light availability, the slow-growing Scenedesmus acuminatus led to the growth of large rotifers (Monogononta sp., $>100 \mu \mathrm{m}$ ), which are able to graze on and control the population of $S$. acuminatus. Overall, the planktivores (both ciliates and rotifers) contributed to $50 \%$ of the total $\mathrm{C}$ biomass produced in the HRAPs (Figure 4). Such high contribution of planktivores is due to their accumulation in the raceways suggesting that the 6-day hydraulic retention time (HRT) was not short enough to wash them out or that they avoided the weir at the outflow. Similarly, large rotifers and cladocerans were found in HRAPs using paddlewheels for mixing, with an HRT of 4 days, during spring and summer [7, 39].

Interestingly, the highest disCOD removal efficiencies were measured when the microalgae biomass was low (Figure 6). This suggests a strong contribution of heterotrophs organisms (bacteria and detrivores) to the disCOD removal, in condition unfavourable to algal accumulation (low light and/or high planktivores). This is supported by the general increase 
of disCOD removal efficiency observed during the last period of the study in the northern site, with values greater than $80 \%$ (Figure 1A), where bacterial abundance was the highest and when microalgae were collapsing. We assumed that the ability of both bacteria and microalgae to exhaust $\mathrm{NH}_{4}{ }^{+}$rapidly as discussed earlier (4.2), would have a direct impact not only on the algal $\mathrm{PO}_{4}{ }^{3-}$ removal but also on the disCOD removal by bacteria that require $\mathrm{N}$ source as well. Therefore, in addition to environmental conditions, microbial interactions within the HRAPs would influence substantially the wastewater treatment and an efficient $\mathrm{C}$ or P removal will be dependent on microorganisms (bacteria or microalgae) that outcompete for $\mathrm{NH}_{4}{ }^{+}$. Similar biological and environmental constraints seemed to be applied on both HRAPs. This suggests that the removal efficiency would be highly reproducible under different temperate latitudes.

\section{Conclusion}

This study, which was carried out under outdoor conditions using urban wastewater influents, demonstrated that there is a similar biological succession and dissolved COD, $\mathrm{NH}_{4}{ }^{+}$and $\mathrm{PO}_{4}{ }^{3-}$ removal efficiencies during the wastewater treatment using a High Rate Algal Pond (HRAP) under both temperate oceanic and Mediterranean climates. The results suggest that water clarification through the consumption of organic matter by detritivores, heterotrophic bacteria, nematodes, amoebozoa initially present in the wastewater, is a prerequisite for a rapid growth of microalgae. Together with the microalgae, bacteria participated substantially to the complete exhaustion of ammonia. The resulting competition for $\mathrm{NH}_{4}{ }^{+}$would drive the level of removal efficiency of disCOD by bacteria and $\mathrm{PO}_{4}{ }^{3-}$ by microalgae. The use of a modelling approach focusing on trophic relationships (i.e. prey-predator, $\mathrm{N}$ competition) could help 
reveal the key biological interactions acting on the overall process efficiency and propose effective control and optimization strategies that could be tested using further experiments.

\section{Acknowledgements}

This study was supported by PHYCOVER project, which was funded by the French National Agency for Research (ANR-14-CE04-0011). We should like to thank Patrick Raimbault (UMR Institut Méditerranéen d'Océanologie, Marseille) for the analyses of the carbon and nitrogen content of the biomass. We thank the two anonymous reviewers for their constructive comments, which improved the manuscript.

\section{Declaration of contributions}

AG, VJ, BS, JPS and EF have worked in the conception and design of the study. AG, AB,

CC, EL, ELF, JP, CP and CR have contributed on the acquisition of data. MS contributed to the statistical analysis of data. AG, VJ, ELF, CR, BS, JPS, EF have realized the interpretation of data and drafted the article.

\section{Conflict of interest statement}

We declare that this manuscript has not any potential financial or other interests that could be perceived to influence the outcomes of the research

\section{Declaration of authors}

All authors have approved the manuscript and agree with peer review process and its submission to Algal Research 


\section{References}

[1] Y. Nurdogan, W.J. Oswald. Enhanced nutrient removal in High-Rate ponds. Water Sci. Tech. 31 (1995) 33-43.

[2] R. Craggs, J. Park, S. Heubeck, D. Sutherland. High rate algal pond systems for lowenergy wastewater treatment, nutrient recovery and energy production. N. Z. J. Bot. 52 (2014) 60-73.

[3] K. Kumar, S.K. Mishra, A. Shrivastav, M.S. Park. Recent trends in the mass cultivation of algae in raceway ponds. Renew. Sust. Energ. Rev. 51 (2015) 875-885.

[4] E. Monflet, A. Unc Defining wastewaters used for cultivation of algae. Algal Res. 24 (2017) 520-526.

[5] A. Gonçalves, J.C.M. Pires, M. Simoes A review on the use of microalgal consortia for wastewater treatment. Algal Res. 24 (2017) 403-415.

[6] D.L. Sutherland, M.H. Turnbull, R.J. Craggs Environmental drivers that influence microalgae species in fullscale wastewater treatment high rate algal ponds. Water Res. 124 (2017) 504-512.

[7] D.-H. Cho, R. Ramanan, J. Heo, Z. Kang, B.-H. Kim, C.-Y. Ahn, H.-M. Oh, H.-S. Kim Organic carbon, influent microbial diversity and temperature strongly influence algal diversity and biomass in raceway ponds treating municipal wastewater. Bioresource Technol. 191 (2015) 481-487.

[8] V. Montemezzani, I.C. Duggan, I.D. Hogg, R.J. Craggs Zooplankton community influence on seasonal performance and microalgal dominance in wastewater treatment High Rate Algal Ponds. Algal Res. 17 (2016) 168-184. 
[9] D.-H. Cho, J.-W. Choi, Z. Kang, B.-H. Kim, H.-M. Oh, H.-S. Kim, R. Ramanan Microalgal diversity fosters stable biomass productivity in open ponds treating wastewater. Sci. Rep. 7 (2017) 1979.

[10] A. Lavrinovičs, T. Juhna. Review on Challenges and Limitations for Algae-Based Wastewater Treatment. Constr. Sci. 20 (2017) 17-25.

[11] P. Raimbault, W. Pouvesle, R. Sempéré, F. Diaz, N. Garcia A simple procedure for simultaneous analysis of total and dissolved organic forms of carbon, nitrogen and phosphorus in seawater using the wet-oxidation technic. Mar. Chem. 66 (1999) 161-169.

[12] J. Murphy, J.P. Riley. A modified single solution method for the determination of phosphate in natural waters. Anal. Chim. Acta 27 (1962) 31-36.

[13] F.I. Koroleff Determination of phosphorus in K. Grasshoff, M. Eberhardt, K. Kremling (Eds.), Methods of Seawater Analysis (second ed.), Verlag Chemie, Weinheimer, FRG, 1983, pp. 125-139.

[14] R.J. Ritchie. Consistent sets of spectrophotometric chlorophyll equations for acetone, methanol and ethanol solvents. Photosynth. Res. 89 (2006) 27-41.

[15] M.H. Long, J.E. Rheuban, P. Berg, J.C. Zieman. A comparison and correction of light intensity loggers to photosynthetically active radiation sensors. Limnol. Oceanogr. - Meth. 10 (2012) 416-424.

[16] J.T. Kirk JT. Light and photosynthesis in aquatic ecosystems. Cambridge university press, 1994, pp. 129-169.

[17] J.J. Kozich, S.L. Westcott, N.T. Baxter, S.K. Highlander, P.D. Schloss .Development of a Dual-Index Sequencing Strategy and Curation Pipeline for Analyzing Amplicon Sequence Data on the MiSeq Illumina Sequencing Platform. Appl. Env. Microb. 79 (2013) 5112-5120. 
[18] P.D. Schloss, S.L. Westcott, T. Ryabin et al. Introducing Mothur: Open-Source, Platform-Independent, Community-Supported Software for Describing and Comparing Microbial Communities. Appl. Env. Microb. 75 (2009) 7537-7541.

[19] Y. Yu, C. Lee, J. Kim, S. Hwang. Group-specific primer and probe sets to detect methanogenic communities using quantitative real-time polymerase chain reaction. Biotechnol. Bioeng. 89 (2005) 670-9.

[20] J. Sun, D. Liu. Geometric models for calculating cell biovolume and surface area for phytoplankton. J. Plankton Res. 25 (2003) 1331-1346.

[21] R. Fukuda, H. Ogawa, T. Nagata, I. Koike. Direct Determination of Carbon and Nitrogen Contents of Natural Bacterial Assemblages in Marine Environments. Appl. Env. Microb. 64 (1998) 3352-3359.

[22] H. Utermöhl. Zur Vervollkommung der quantitativen Phytoplankton-Methodik. Mitt Int Ver Theor. Angew Limnol. 9 (1958) 1-38.

[23] AFNOR. Standard guide for phytoplankton enumeration by reverse microscopy Utermöhl technique (Norme guide pour le dénombrement du phytoplancton par microscopie inverse - méthode Utermöhl). Comité Technique CEN/TC 230 “Analyse de l'eau”, 2006.

[24] J.W.G. Lund, C. Kipling, E.D. Lecren. The inverted microscope method of estimating algal number and the statistical basis of estimating by counting. Hydrobiologia 11 (1958) 143-170.

[25] H. Hillebrand, C.D. Dürselen, D. Kirschtel, D. Pollingher, T. Zohary. Biovolume calculation for pelagic and benthic microalgae. J. Phycol. 35 (1999) 403-424.

[26] J. Sun, D. Liu. Geometric models for calculating cell biovolume and surface area for phytoplankton. J. Plankton Res. 25 (2003) 1331-1346. 
[27] M.M. Mullin, P.R. Sloan, R.W. Eppley Relationship between carbon content, cell volume and area in phytoplankton. Limnol. Oceanogr. 11 (1966) 307-311.

[28] M.D. Pizay-Parenty. Bassins de lagunage d'Aniche-Auberchicourt (Nord) : Cinétiques saisonnières et spatiales du zooplancton et des descripteurs de la qualité de l'eau. PhD thesis, Lille, Université des Sciences et Techniques, 1985.

[29] H. Bottrel, A. Duncan, Z.M. Gliwicz, E. Grygierek, A. Herzig, H. Hilbricht-Ilkowsaka, Kurasawa, P. Larsson, T. Weglensca. A review of some problems in Zooplankton production studies. Norw. J. Zol. 24 (1976) 419 - 456.

[30] B. Widbom. Determination of average individual dry weights and ash-free dry weights in different sieve fractions of marine meiofauna. Mar. Biol. 84 (1984) 101-108.

[31] O. Hammer, D.A.R. Harper, P.D. Ryan. PAST: paleontological statistics software package for education and data analysis. Palaeontol. Electron. 4 (2001) 1-9.

[32] B.-J. Ni, Y. Pan, J. Guo, B. Virdis, S. Hu, X. Chen, Z. Yuan. Denitrification processes for wastewater treatment in I. Moura, J.J.G. Moura, S.R. Pauleta, L.B. Maia (Eds.), Metalloenzymes in denitrification: Applications and environmental impacts, The Royal Society of Chemistry, 2017, pp. 368-418.

[33] V. Unnithan, A. Unc, G.B. Smith. Mini-review: A priori considerations for bacteriaalgae interactions in algal biofuel systems receiving municipal wastewaters. Algal Res. 4 (2013) 35-40.

[34] S.K. Gupta, F.A. Ansari, A. Shriwastav, N.K. Sahoo, I. Rawat, F. Bux Dual role of Chlorella sorokiniana and Scenedesmus obliquus for comprehensive wastewater treatment and biomass production for bio-fuels. J. Cleaner Prod. 1115 (2016) 255-264. 
[35] P. Wunderlin, J. Mohn, A. Joss, L. Emmenegger, H. Siegrist. Mechanisms of $\mathrm{N}_{2} \mathrm{O}$ production in biological wastewater treatment under nitrifying and denitrifying conditions. Water Res. 46 (2012) 1027-1037.

[36] K.D. Fagerstone, J.C. Quinn, T.H. Bradley, S.K. De Long, A.J. Marchese. Quantitative measurement of direct nitrous oxide emissions from microalgae cultivation. Environ. Sci. Technol. 45 (2011) 9449-9456.

[37] T. Harter, P. Bossier, J. Verreth, S. Bodé, D. Van der Ha, A.E. Debeer, N. Boon, P. Boeckx, W. Vyverman, N. Nevejan Carbon and nitrogen mass balance during flue gas treatment with Dunaliella salina cultures. J. Appl. Phycol. 25 (2013) 359-368.

[38] O. Choi, A. Das, C.-P. Yu, Z. Hu. Nitrifying bacterial growth inhibition in the presence of algae and cyanobacteria. Biotechnol. Bioeng. 107 (2010) 1004-1011.

[39] K.A. Safi, J.B.K. Park, R.J. Craggs. Partitioning of wastewater treatment high rate algal pond biomass and particulate carbon. Algal Res. 19 (2016) 77-85. 


\section{Supplementary data}

S1- Figure: Incident light and water temperature measured at the (A) northern and (B) southern site. Incident light data was missing for several periods at the southern site.

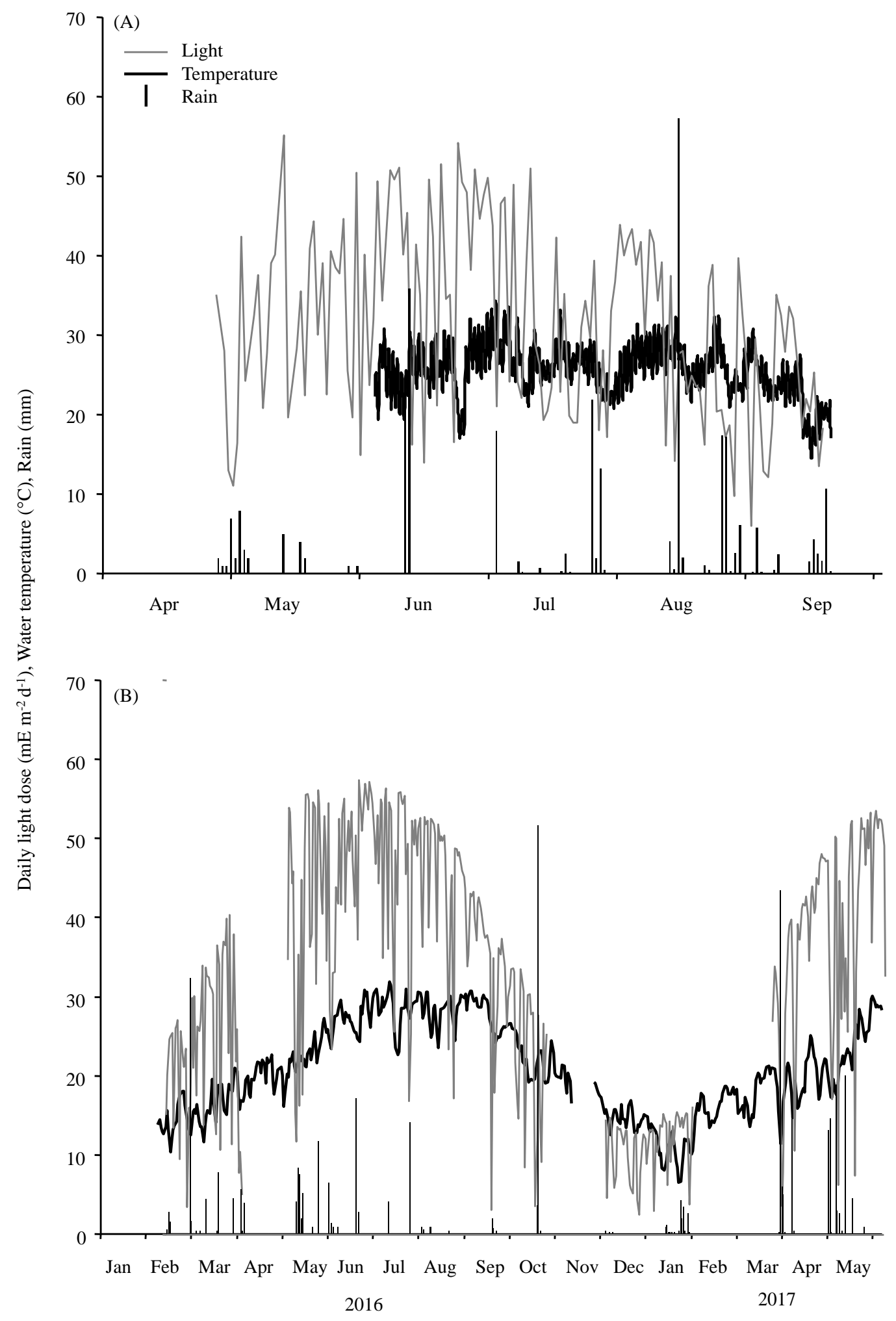


S2-Table: Carbon (POC), Nitrogen (PON), Phosphorus (POP) and chlorophyll $a$ (Chl $a$ ) content (mean and standard deviation from triplicated samples) in the biomass in the northern and southern HRAPs during the study period.

Northern HRAP

Southern HRAP

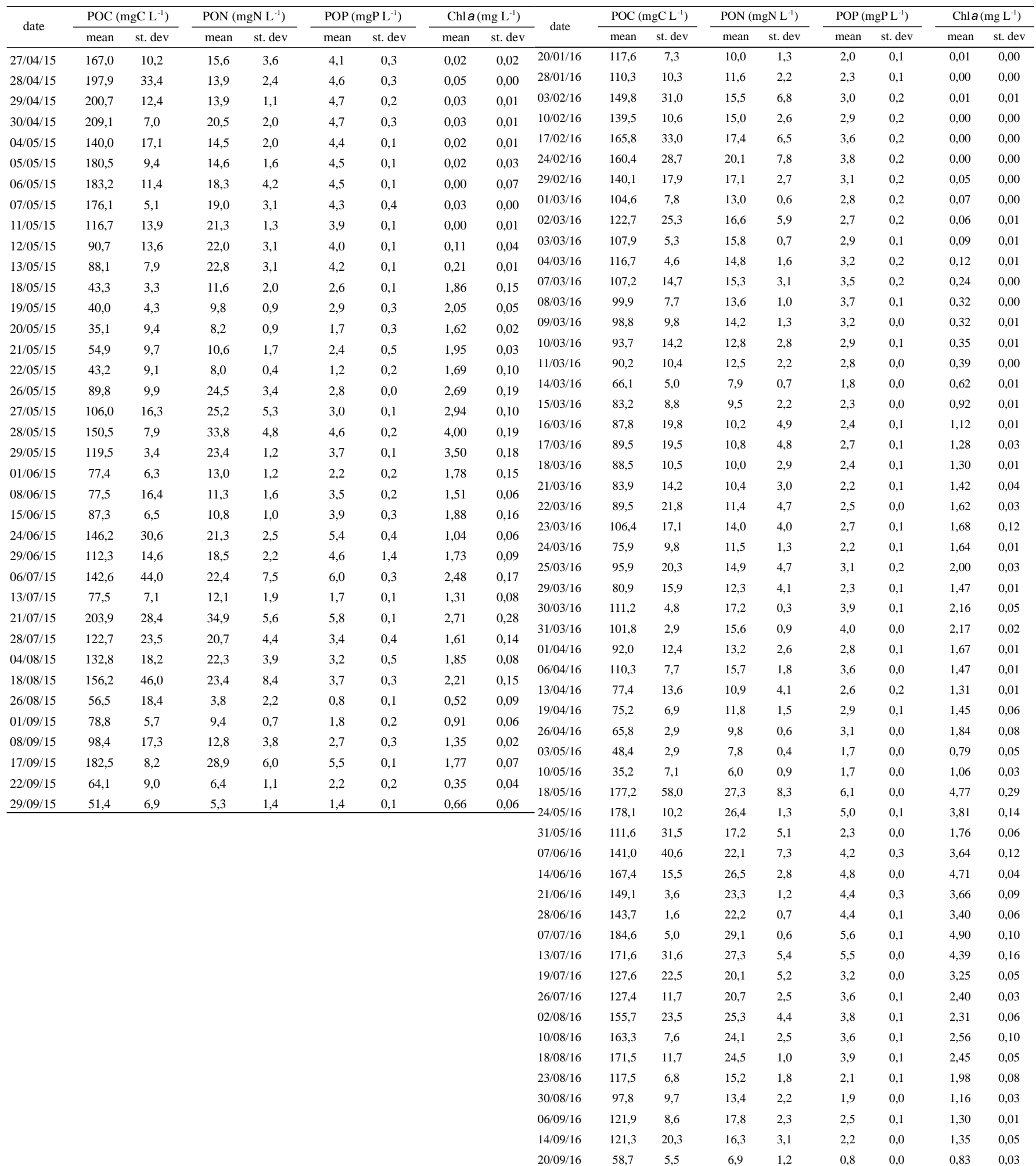


S3- Figure: Bacterial abundance (cells. $\mathrm{L}^{-1}$ ) and the relative abundance of bacterial classes (\%) as a function of time in (A) the northern HRAP and (B) the southern HRAP.

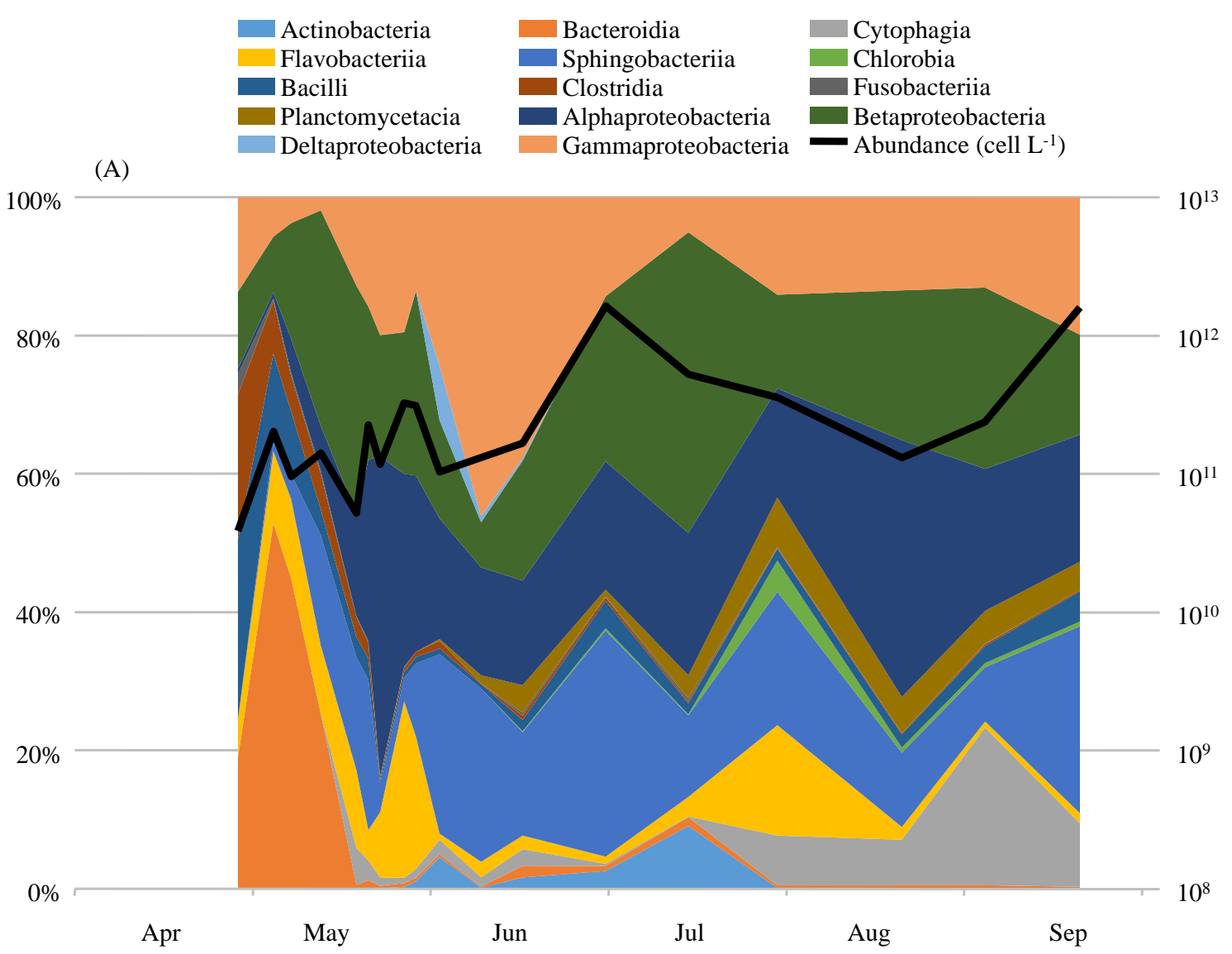

(B)

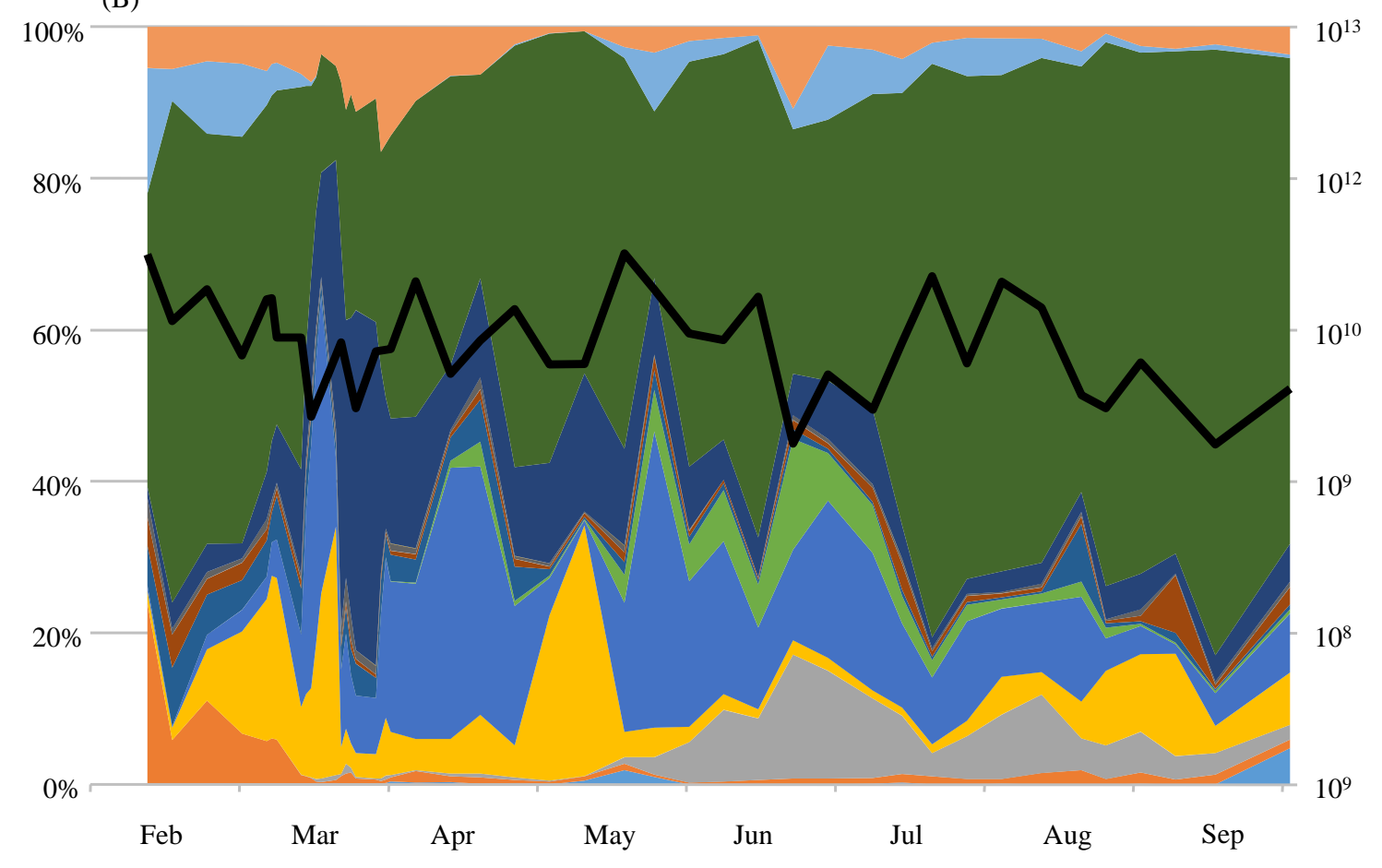


S4-Table: Identification, biovolume and abundance of all the microalgal species identified by microscopy in the northern and southern HRAPs

\begin{tabular}{|c|c|c|c|c|c|c|c|c|c|c|c|c|c|c|c|c|c|c|c|}
\hline \multirow{2}{*}{ Phyla } & \multirow{2}{*}{ Class } & \multirow{2}{*}{ Order } & \multirow{2}{*}{ Genus species } & \multirow{2}{*}{$\begin{array}{c}\text { BIOVOLUME } \\
\left(\mu \mathrm{m}^{3}\right)\end{array}$} & \multicolumn{7}{|c|}{ Northern HRAP } & \multicolumn{8}{|c|}{ Southern HRAP } \\
\hline & & & & & $28 / 04 / 15$ & $18 / 05 / 15$ & $01 / 06 / 15$ & $24 / 06 / 15$ & $13 / 07 / 15$ & $04 / 08 / 15$ & 01/09/15 & 20/01/16 & $14 / 03 / 16$ & $13 / 04 / 16$ & $24 / 05 / 16$ & $21 / 06 / 16$ & 19/07/16 & $30 / 08 / 16$ & $29 / 09 / 16$ \\
\hline \multirow[t]{16}{*}{ Cyanobacteria } & Cyanophyceae & Chroococcales & Aphanothece sp & 15,63 & & & & & & & & & & & & & & $1,4 \mathrm{E}+06$ & \\
\hline & & & Chroococcus sp. & 28,78 & & & & $1,1 \mathrm{E}+06$ & & $4,2 \mathrm{E}+06$ & $2,3 \mathrm{E}+06$ & & & & & & & & $2,2 \mathrm{E}+07$ \\
\hline & & & Microcystis sp. & 20,12 & & & & & & & & & & $2,1 E+06$ & & $1,5 \mathrm{E}+06$ & & $7,0 \mathrm{E}+06$ & \\
\hline & & & cf Xenococcaceae & 902,8 & & & & $1,1 \mathrm{E}+07$ & & & $4,5 \mathrm{E}+06$ & & & & & $3,1 E+06$ & $5,1 E+08$ & $6,0 E+06$ & $3,6 \mathrm{E}+07$ \\
\hline & & Pseudanabaenales & cf Pseudanabaena sp1 & 248,68 & & $9,8 \mathrm{E}+06$ & $6,8 \mathrm{E}+06$ & $1,1 \mathrm{E}+06$ & $8,8 \mathrm{E}+05$ & $1,1 \mathrm{E}+06$ & & & & & & & & & $3,9 \mathrm{E}+06$ \\
\hline & & & cf Pseudanabaena sp2 & 18,01 & & & & & & & & & & & $2,6 \mathrm{E}+06$ & $2,3 E+06$ & $1,5 \mathrm{E}+06$ & $1,9 \mathrm{E}+06$ & \\
\hline & & & cf Leptolyngbya sp. & 47,81 & Observed & $1,5 \mathrm{E}+06$ & $4,5 \mathrm{E}+06$ & $1,1 \mathrm{E}+06$ & & & & $2,4 \mathrm{E}+07$ & $3,3 \mathrm{E}+06$ & $3,2 \mathrm{E}+06$ & $1,6 \mathrm{E}+07$ & & & & $7,7 \mathrm{E}+05$ \\
\hline & & Oscillatoriales & Oscillatoria sp. & 807,51 & Observed & & & & & & & & $6,6 \mathrm{E}+05$ & $1,1 \mathrm{E}+06$ & & & & & \\
\hline & & & Lyngbya sp. & 345,45 & & & & $1,1 \mathrm{E}+06$ & & & & & & & & & & & \\
\hline & & & Spirulina sp. & 46,26 & & & & & & & & & $1,3 \mathrm{E}+06$ & & & & & & \\
\hline & & & cf Planktolyngbya sp1 & 31,86 & & $1,7 \mathrm{E}+07$ & $2,1 \mathrm{E}+07$ & $1,3 \mathrm{E}+07$ & $7,0 \mathrm{E}+06$ & $8,4 \mathrm{E}+06$ & & $8,8 \mathrm{E}+06$ & $5,9 \mathrm{E}+06$ & $3,6 \mathrm{E}+07$ & $6,2 \mathrm{E}+07$ & $7,0 E+06$ & $4,6 \mathrm{E}+06$ & $1,4 \mathrm{E}+06$ & $6,2 \mathrm{E}+06$ \\
\hline & & & Planktolyngbya sp2 cf limnetica & 9,55 & Observed & & & $1,1 \mathrm{E}+08$ & $8,8 E+05$ & & & & & & & $3,3 E+07$ & $1,9 \mathrm{E}+07$ & $4,6 \mathrm{E}+06$ & $6,2 \mathrm{E}+06$ \\
\hline & & & unidentified Oscillatoriale 1 & 140,54 & & $2,3 E+06$ & & & & $1,1 \mathrm{E}+06$ & $5,3 E+06$ & & & & & & & & \\
\hline & & & unidentified Oscillatoriale 2 & 1845,78 & & & & & & & & & & & & & & & $8,5 \mathrm{E}+06$ \\
\hline & & Nostocales & Anabaena sp. & 9,058 & & & & & & & & & $3,3 \mathrm{E}+06$ & & & & & & \\
\hline & & & Cf Anabaena sp. & 59,82 & & & & & & & & $1,6 \mathrm{E}+06$ & & & & & & & \\
\hline \multirow[t]{8}{*}{ Chlorophyta } & Trebouxiophyceae & Chlorellales & Chlorella sp. & 16,842 & Observed & $3,4 \mathrm{E}+09$ & $3,8 \mathrm{E}+09$ & $4,5 \mathrm{E}+07$ & $9,6 \mathrm{E}+06$ & $3,2 \mathrm{E}+06$ & & & $1,2 \mathrm{E}+09$ & $2,5 \mathrm{E}+09$ & $3,9 \mathrm{E}+09$ & $2,8 \mathrm{E}+09$ & $2,5 \mathrm{E}+09$ & & \\
\hline & Chlorophyceae & Sphaeropleales & Scenedesmus acuminatus & 137,96 & Observed & $2,1 E+07$ & $2,3 E+08$ & $1,1 E+09$ & $9,2 E+08$ & $1,7 \mathrm{E}+09$ & $5,8 E+08$ & $2,4 \mathrm{E}+05$ & & & $2,4 \mathrm{E}+07$ & $9,5 E+07$ & $3,6 E+08$ & $1,4 \mathrm{E}+09$ & $1,3 E+09$ \\
\hline & & & Scenedesmus sp2 & 15,08 & & & & $4,2 E+06$ & & & & & & & & & & & \\
\hline & & & Scenedesmus sp3 & 93,02 & & $3,0 E+06$ & $3,0 E+06$ & & & $3,2 \mathrm{E}+06$ & & & & & & & $3,1 E+06$ & & $3,1 \mathrm{E}+06$ \\
\hline & & & Scenedesmus sp4 & 173,26 & & & & & & & & & & & & & & & $6,2 \mathrm{E}+06$ \\
\hline & & & Monoraphidium sp cf griffithii & 259,01 & & & & $5,3 E+06$ & $2,3 \mathrm{E}+07$ & $4,5 E+07$ & $2,9 \mathrm{E}+07$ & & & & & & & & \\
\hline & & & Unidentified Chlorophyceae 4 & 2450,56 & & & & $1,1 \mathrm{E}+06$ & & & & & $2,0 \mathrm{E}+06$ & $1,2 \mathrm{E}+07$ & $1,4 \mathrm{E}+07$ & $7,7 E+06$ & $6,2 \mathrm{E}+06$ & $1,7 \mathrm{E}+07$ & $1,0 \mathrm{E}+07$ \\
\hline & & & Unidentified Chlorophyceae 5 & 448,43 & & & & $1,1 \mathrm{E}+06$ & & & & & & & & $4,6 \mathrm{E}+06$ & $7,7 E+05$ & $4,6 \mathrm{E}+05$ & \\
\hline \multirow[t]{5}{*}{ Ochrophyta } & Bacillariophyceae (diatoms) & & Cf Cyclotella sp. & 441,39 & & & & & & & & & & & $1,3 \mathrm{E}+06$ & $7,7 E+05$ & & & \\
\hline & & Bacillariales & Nitzschia sp1 & 197,23 & & & $1,2 \mathrm{E}+07$ & $2,1 E+06$ & & $1,1 \mathrm{E}+06$ & & & $6,6 \mathrm{E}+05$ & $1,4 \mathrm{E}+07$ & $1,2 \mathrm{E}+07$ & & & & \\
\hline & & & Nitzschia sp2 & 139,22 & & & & & & & & & & & & $5,9 \mathrm{E}+07$ & $1,9 \mathrm{E}+08$ & $6,5 \mathrm{E}+07$ & $5,0 E+07$ \\
\hline & & Naviculaceae & Navicula sp. & 247,87 & & & & & & & & & & $7,4 \mathrm{E}+06$ & & & & & \\
\hline & & & Unidentified Naviculaeae & 971,18 & & & & & & & & & & $8,4 \mathrm{E}+06$ & $1,6 \mathrm{E}+07$ & & & & \\
\hline \multirow[t]{3}{*}{ Cryptophyta } & Cryptophyceae & Pyrenomonadales & Rhodomonas sp. & 23,39 & & $4,0 E+07$ & $3,0 E+06$ & $3,2 \mathrm{E}+06$ & $4,4 \mathrm{E}+06$ & $1,1 \mathrm{E}+06$ & $1,5 \mathrm{E}+06$ & $8,0 \mathrm{E}+04$ & $2,1 \mathrm{E}+07$ & $2,1 \mathrm{E}+06$ & & & & & \\
\hline & & & Unidentified Cryptophyceae 1 & 33,51 & & & & & & & & & & $7,2 E+07$ & $6,6 \mathrm{E}+06$ & & & & \\
\hline & & & Unidentified Cryptophyceae 2 & 322,02 & & & & & & $3,2 \mathrm{E}+06$ & & & & & & & $7,7 \mathrm{E}+05$ & & \\
\hline Euglenozoa & Euglenoidea & Euglenida & Unidentified Euglenaceae & 269,97 & & & & & $8,8 \mathrm{E}+05$ & & & & $1,3 \mathrm{E}+06$ & $1,1 \mathrm{E}+06$ & & & & & $7,7 \mathrm{E}+05$ \\
\hline
\end{tabular}


S5-Table: Abundance of all the main groups of protozoans and metazoans identified by microscopy in the northern and southern HRAPs

\begin{tabular}{|c|c|c|c|c|c|c|c|c|c|c|c|c|c|c|c|}
\hline \multirow{2}{*}{ Size fraction } & \multirow{2}{*}{ Group (ind $\mathrm{L}^{-1}$ ) } & \multicolumn{7}{|c|}{ Northern HRAP } & \multicolumn{7}{|c|}{ Southern HRAP } \\
\hline & & $28 / 04 / 15$ & $18 / 05 / 15$ & $02 / 06 / 15$ & $24 / 06 / 15$ & $13 / 07 / 15$ & $04 / 08 / 15$ & $01 / 09 / 15$ & $20 / 01 / 16$ & $14 / 03 / 16$ & $13 / 04 / 16$ & $24 / 05 / 16$ & $21 / 06 / 16$ & $19 / 07 / 16$ & $30 / 08 / 16$ \\
\hline \multirow{7}{*}{$35-100 \mu \mathrm{m}$} & Free ciliates & & $2.5 \mathrm{E}+03$ & $5.0 \mathrm{E}+03$ & $7.0 \mathrm{E}+04$ & $4.4 \mathrm{E}+04$ & $7.5 \mathrm{E}+04$ & $2.2 \mathrm{E}+05$ & & & & $4.4 \mathrm{E}+04$ & $6.4 \mathrm{E}+05$ & & $1.7 \mathrm{E}+04$ \\
\hline & Attached Ciliates & $1.4 \mathrm{E}+03$ & $1.7 \mathrm{E}+05$ & $4.6 \mathrm{E}+05$ & $1.9 \mathrm{E}+04$ & $2.8 \mathrm{E}+04$ & $3.2 \mathrm{E}+05$ & $1.6 \mathrm{E}+05$ & & $1.0 \mathrm{E}+04$ & $6.4 \mathrm{E}+03$ & $4.4 \mathrm{E}+04$ & $4.2 \mathrm{E}+05$ & $5.0 \mathrm{E}+05$ & $1.4 \mathrm{E}+05$ \\
\hline & Rhizopods & $6.0 \mathrm{E}+05$ & $7.6 \mathrm{E}+05$ & $3.5 \mathrm{E}+05$ & $3.2 \mathrm{E}+05$ & $6.6 \mathrm{E}+04$ & $2.5 \mathrm{E}+05$ & $2.6 \mathrm{E}+05$ & $1.0 \mathrm{E}+05$ & $1.0 \mathrm{E}+05$ & $2.1 \mathrm{E}+05$ & $1.7 \mathrm{E}+06$ & $1.1 \mathrm{E}+06$ & $1.4 \mathrm{E}+06$ & $7.9 \mathrm{E}+05$ \\
\hline & Actinopods & & & $9.0 \mathrm{E}+03$ & & $2.0 \mathrm{E}+03$ & $1.7 \mathrm{E}+03$ & $1.4 \mathrm{E}+04$ & & & & & $1.5 \mathrm{E}+04$ & $2.4 \mathrm{E}+04$ & \\
\hline & Rotifers & & & $2.5 \mathrm{E}+03$ & $2.9 \mathrm{E}+05$ & $1.4 \mathrm{E}+04$ & $1.7 \mathrm{E}+05$ & $1.8 \mathrm{E}+05$ & & & & $3.3 \mathrm{E}+04$ & $9.0 \mathrm{E}+04$ & $1.2 \mathrm{E}+05$ & $6.7 \mathrm{E}+05$ \\
\hline & Nematods & & $2.5 \mathrm{E}+03$ & $4.5 \mathrm{E}+03$ & $2.0 \mathrm{E}+03$ & $1.0 \mathrm{E}+03$ & & $3.3 \mathrm{E}+03$ & & & & & & & \\
\hline & Eggs & & & & & $7.0 \mathrm{E}+03$ & $5.0 \mathrm{E}+03$ & $2.3 \mathrm{E}+04$ & & & & & $3.0 \mathrm{E}+04$ & $7.2 \mathrm{E}+04$ & \\
\hline \multirow{4}{*}{$>100 \mu \mathrm{m}$} & Nematods & & $4.4 \mathrm{E}+01$ & $2.2 \mathrm{E}+02$ & $1.9 \mathrm{E}+02$ & $5.4 \mathrm{E}+02$ & $3.1 \mathrm{E}+02$ & $4.4 \mathrm{E}+02$ & & $7.7 \mathrm{E}+01$ & $1.8 \mathrm{E}+02$ & $9.9 \mathrm{E}+01$ & $5.0 \mathrm{E}+02$ & $2.2 \mathrm{E}+02$ & $4.4 \mathrm{E}+01$ \\
\hline & Rotifers & & & & $5.9 \mathrm{E}+02$ & $8.4 \mathrm{E}+02$ & $1.3 \mathrm{E}+03$ & $3.1 \mathrm{E}+03$ & & & & $1.1 \mathrm{E}+01$ & $1.1 \mathrm{E}+01$ & $3.6 \mathrm{E}+03$ & $3.9 \mathrm{E}+03$ \\
\hline & Ciliates & & & & & & & & & & & $1.5 \mathrm{E}+02$ & $1.1 \mathrm{E}+02$ & & \\
\hline & Copepods & & & & & & & & & & & & $1.1 \mathrm{E}+01$ & & \\
\hline
\end{tabular}


S6-Figure: The concentrations of ammonia $\left(\mathrm{NH}_{4}{ }^{+}\right)$, nitrite $\left(\mathrm{NO}_{2}{ }^{-}\right)$and nitrate $\left(\mathrm{NO}_{3}{ }^{-}\right)$and the $\mathrm{N}$ biomass produced through microalgal growth measured in (A) the northern HRAP and (C) the southern HRAP. The concentrations of phosphate $\left(\mathrm{PO}_{4}{ }^{3-}\right)$ and $\mathrm{P}$-biomass produced through microalgal growth measured in (B) the northern HRAP and (D) the southern HRAP. The N- and Pbiomass produced through microalgal growth (after clarification of waters) was estimated using the nitrogen (PON) and phosphorus (POP) content of the total biomass in the HRAPs. The PON and POP measured in the HRAPs during the microalgal growth consisted of both the biomass growing in the HRAPs and the biomass coming from wastewaters continuously (i.e. 1/6 of the HRAP volume every day). The wastewater biomass corresponds to the PON and POP measured during the first weeks before the growth of microalgae in the HRAPs. The PON and POP produced in the HRAPs were therefore estimates as the PON and POP concentrations measured in the HRAPs less $1 / 6$ of the PON and POP measured before the growth of microalgae.
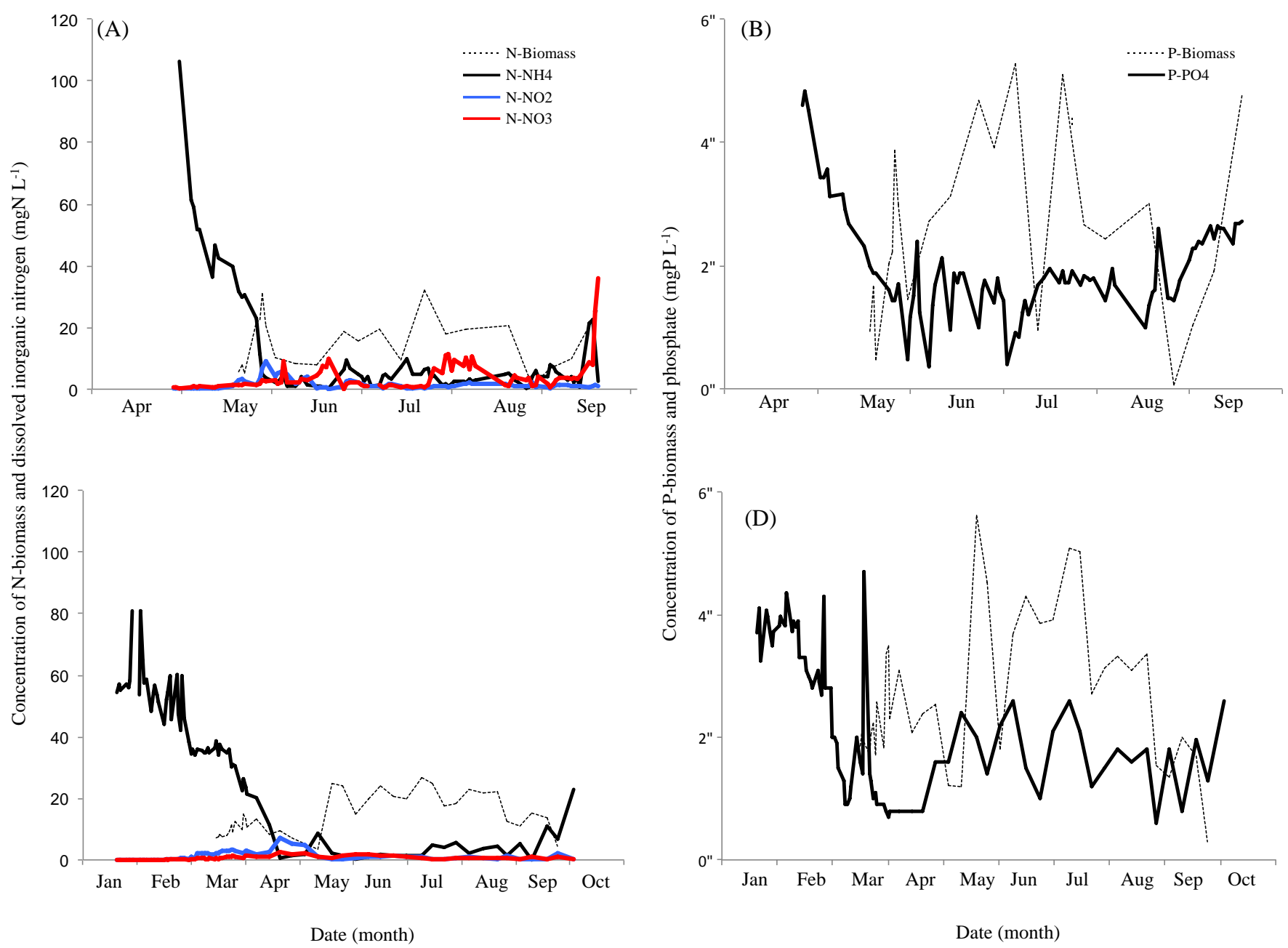